\section{(6) OPEN ACCESS}

\title{
Multitrait genome association analysis identifies new susceptibility genes for human anthropometric variation in the GCAT cohort
}

\author{
Iván Galván-Femenía, ${ }^{1}$ Mireia Obón-Santacana, ${ }^{1,2}$ David Piñeyro, ${ }^{3}$ \\ Marta Guindo-Martinez, ${ }^{4}$ Xavier Duran, ${ }_{1}^{1}$ Anna Carreras, ${ }^{1}$ Raquel Pluvinet, ${ }_{1}^{3}$ \\ Juan Velasco, ${ }^{1}$ Laia Ramos, ${ }^{3}$ Susanna Aussó, ${ }^{3}$ J M Mercader, ${ }^{5,6}$ Lluis Puig, ${ }^{7}$ \\ Manuel Perucho, ${ }^{8}$ David Torrents, ${ }^{4,9}$ Victor Moreno, ${ }^{2,10}$ Lauro Sumoy, $^{3}$ Rafael de Cid ${ }^{1}$
}

\begin{abstract}
- Additional material is published online only. To view, please visit the journal online (http://dx.doi.org/10.1136/ jmedgenet-2018-105437).
\end{abstract}

For numbered affiliations see end of article.

\section{Correspondence to} Dr Rafael de Cid, GCAT lab Group, Program of Predictive and Personalized Medicine of Cancer (PMPPC), Germans Trias i Pujol Research Institute (IGTP), Crta. de Can Ruti, Badalona 08916, Spain; rdecid@igtp.cat

Received 24 April 2018

Revised 19 July 2018

Accepted 21 July 2018

Published Online First 30 August 2018

\section{Check for updates}

(C) Author(s) (or their employer(s)) 2018. Re-use permitted under CC BY-NC. No commercial re-use. See rights and permissions. Published by BMJ.

To cite: Galván-Femenía I, Obón-Santacana $\mathrm{M}$,

Piñeyro D, et al. J Med Genet 2018:55:765-778.

\section{ABSTRACT}

Background Heritability estimates have revealed an important contribution of SNP variants for most common traits; however, SNP analysis by single-trait genomewide association studies (GWAS) has failed to uncover their impact. In this study, we applied a multitrait GWAS approach to discover additional factor of the missing heritability of human anthropometric variation.

Methods We analysed 205 traits, including diseases identified at baseline in the GCAT cohort (Genomes For Life- Cohort study of the Genomes of Catalonia) ( $n=4988)$, a Mediterranean adult population-based cohort study from the south of Europe. We estimated SNP heritability contribution and single-trait GWAS for all traits from 15 million SNP variants. Then, we applied a multitraitrelated approach to study genome-wide association to anthropometric measures in a two-stage meta-analysis with the UK Biobank cohort ( $n=336$ 107).

Results Heritability estimates (eg, skin colour, alcohol consumption, smoking habit, body mass index, educational level or height) revealed an important contribution of SNP variants, ranging from $18 \%$ to $77 \%$. Single-trait analysis identified 1785 SNPs with genome-wide significance threshold. From these, several previously reported single-trait hits were confirmed in our sample with LINC01432 $\left(p=1.9 \times 10^{-9}\right)$ variants associated with male baldness, $L D L R$ variants with hyperlipidaemia (ICD-9:272) $\left(p=9.4 \times 10^{-10}\right)$ and variants in IRF4 $\left(p=2.8 \times 10^{-57}\right)$, SLC45A2 $\left(p=2.2 \times 10^{-130}\right)$, HERC2 $\left(p=2.8 \times 10^{-176}\right)$, OCA2 $\left(p=2.4 \times 10^{-121}\right)$ and MC1R $\left(p=7.7 \times 10^{-22}\right)$ associated with hair, eye and skin colour, freckling, tanning capacity and sun burning sensitivity and the Fitzpatrick phototype score, all highly correlated crossphenotypes. Multitrait meta-analysis of anthropometric variation validated 27 loci in a two-stage metaanalysis with a large British ancestry cohort, six of which are newly reported here ( $p$ value threshold $<5 \times 10^{-9}$ ) at ZRANB2-AS2, PIK3R1, EPHA7, MAD1L1, CACUL 1 and MAP3K9.

Conclusion Considering multiple-related genetic phenotypes improve associated genome signal detection. These results indicate the potential value of data-driven multivariate phenotyping for genetic studies in large population-based cohorts to contribute to knowledge of complex traits.

\section{INTRODUCTION}

Common disorders cause $85 \%$ of deaths in the European Union (EU). ${ }^{1}$ The increasing incidence and prevalence of cancer, cardiovascular diseases, chronic respiratory diseases, diabetes and mental illness represent a challenge that leads to extra costs for the healthcare system. Moreover, as European population is getting older, this scenario will be heightened in the next few years. Like complex traits, many common diseases are complex inherited conditions with genetic and environmental determinants. Advancing in their understanding requires the use of multifaceted and long-term prospective approaches. Cohort analyses provide an exceptional tool for dissecting the architecture of complex diseases by contributing knowledge for evidence-based prevention, as exemplified by the Framingham Heart Study ${ }^{2}$ or the European Prospective Investigation into Cancer and Nutrition cohort study. ${ }^{3}$

In the last decades, high performance DNA genotyping technology has fuelled genomic research in large cohorts, having been the most promising line in research on the aetiology of most common diseases. Genome-wide association studies (GWAS) have provided valuable information for many single conditions. ${ }^{4}$ Despite the perception of the limitations of the GWAS analyses, efforts combining massive data deriving from whole-genome sequencing at population scale with novel conceptual and methodological analysis frameworks have been set forth to explore the last frontier of the missing heritability issue, ${ }^{5}$ driving the field of genomic research on complex diseases to a new age. ${ }^{6}$ Pritchard and colleagues recently proposed the breakthrough idea of the omnigenic character of genetic architecture of diseases and complex traits. ${ }^{7}$ They suggested that beyond a handful of driver genes (ie, core genes) directly connected to an illness, the missing heritability could be accounted for by multiple genes (ie, peripheral genes) not clustered in functional pathways, but dispersed along the genome, explaining the pleiotropy frequently seen in most complex traits. Core genes have been already outlined by the GWAS approach, but most of the possible contributing genes have been disregarded based on methodological issues such as $\mathrm{p}$ value or lower minor 
allele frequency (MAF). Pathway disturbances have also been a landmark in the search for genetic associations, ${ }^{8}$ but not always appear to the root of the mechanism of inheritance of complex diseases, at least for peripheral genes. ${ }^{7}$ With this challenging vision, a multitrait genome association analysis of the whole phenome ${ }^{9}$ becomes a more appropriate way to detect peripheral gene variation effects and new network disturbances affecting core genes. Multitrait analysis approaches are developed for research of genetically complex conditions using raw or summary-level data statistics from GWAS in order to explain the largest possible amount of the covariation between SNPs and traits. ${ }^{10-15}$

The contribution of total genetic variation, known as heritability (broad-sense heritability, $h^{2}$ ), is estimated now from genome-wide studies in large cohorts directly from SNP data (known as $\mathrm{h}^{2} \mathrm{SNP}$ ). However, even if most disease conditions have a strong genetic basis, it is well known that our capacity to find genetic effects depends on the overall genetic contribution of the trait. Overall estimations differed depending on the ancestry, sample ascertainment, gender and age of the population under study. Recently, data from the UK Biobank determined genetic contributions with a phenome-based approach ${ }^{16}$ and identified a shared familial environment as a significant important factor besides genetic heritability values in 12 common diseases analysed. $^{17}$

In this study, we present new data on phenotype-wide estimation of the heritability of 205 complex traits (including diseases) and new insights into the genetics of anthropometric traits in a Mediterranean Caucasian population using a two-stage meta-analysis approach with multiple-related phenotypes (MRPs).

\section{MATERIALS AND METHODS Population}

The methodology of the GCAT study has been previously described. ${ }^{18}$ Briefly, the subjects of the present study are part of the GCAT project, a prospective study that includes a cohort of a total of 19267 participants recruited from the general population of Catalonia, a western Mediterranean region in the Northeast of Spain. Healthy general population volunteers between 40 and 65 years with the sole condition of being users of the Spanish National Health Service were invited to be part of the study mostly through the Blood and Tissue Bank, a public agency of the Catalan Department of Health. All eligible participants signed an informed consent agreement form and answered a comprehensive epidemiological questionnaire. Anthropometric measures and blood samples were also collected at baseline by trained healthcare personnel. The GCAT study was approved by the local ethics committee (Germans Trias University Hospital) in 2013 and started on 2014.

\section{Study participants}

This study analyses the GCATcore data, a subset of 5459 participants (3066 women) with genotype data belonging to the interim GCATdataset, August 2017 (see the URLs section). GCATcore participants were randomly selected from whole cohort based on overall demographic distribution (ie, gender, age, residence). In this study, in order to increase the robustness of heritability estimates, only Caucasian participants with a Spanish origin (based on principal component analysis (PCA) analysis, see later in this section) and with available genetic data were finally included: 4988 GCAT participants (2777 women). All samples passed genotyping quality control (QC) (see later in this section).

\section{Phenome}

Baseline variables were obtained from a self-reported epidemiological questionnaire and included biological traits, medical diagnoses, drug use, lifestyle habits and sociodemographic and socioeconomic variables. ${ }^{18}$ Description of GCAT variables dataset is available at GCAT (see the URLs section). To keep as many as possible of the genotyped samples in the study, we imputed anthropometric missing values $(<1 \%)$ from the overall distribution values using statistical approaches. Missing values $(<1 \%)$ for biological and anthropometric measures (height, weight, waist and hip circumference, systolic and diastolic blood pressure and heart rate) were imputed by stratifying the whole GCAT cohort by gender and age and using multiple imputation by the fully conditional specification method, implemented in the $\mathrm{R}$ mice package. ${ }^{19}$ For GWAS analysis, we retained all variables with at least five observations $(n=205)$. For heritability estimates, only variables with at least 500 individuals per class were retained $(n=96)$ for robustness. The description of the traits and measures included in this study is summarised in online supplementary table S1.

\section{Genotyping, relatedness and population structure}

Genotyping of the 5459 GCAT participants (GCATcore) was done using the Infinium Expanded Multi-Ethnic Genotyping Array $\left(\mathrm{MEGA}^{\mathrm{Ex}}\right.$ ) (ILLUMINA, San Diego, California, USA). A customised cluster file was produced from the entire sample dataset and used for joint calling. We applied PCA to detect any hidden substructure and the method of moments for the estimation of identity by descent probabilities to exclude cases with cryptic relatedness. The extensive QC protocol used for cluster analysis and call filtering is accessible at GCAT (see the URLs section) and presented as supplementary material (online supplementary file S1). Briefly, GCAT participants were excluded from the analysis for different reasons, including poor call rate $<0.94$ $(n=61)$, gender mismatch $(n=19)$, duplicates $(n=8)$, family relatedness up to second degree $(n=88)$ and excess or loss of heterozygosity $(n=52)$. Non-Caucasian individuals detected as outliers in the PCA plot of the European populations from the 1000 Genomes Project $(n=96)$ and born outside of Spain $(n=147)$ were also excluded from the study. After QC and filtering, 4988 GCAT participants and 1652023 genetic variants were included. Genotyping was performed at the PMPPCIGTP High Content Genomics and Bioinformatics Unit.

\section{Multipanel imputation}

For imputation analysis, 665592 SNPs were included (40\%). Sexual and mitochondrial chromosomes were discarded as well as autosomal chromosome variants with MAF $<0.01$ and AT-CG sites. We followed a two-stage imputation procedure, which consists of prephasing the genotypes into whole chromosome haplotypes followed by imputation itself. ${ }^{20}$ The prephasing was performed using SHAPEIT2, and genotype imputation was performed with IMPUTE2. As reference panels for genotype imputation, we used the 1000 Genomes Project phase $3,{ }^{21}$ the Genome of the Netherlands, ${ }^{22} \mathrm{UK} 10 \mathrm{~K}^{23}$ and the Haplotype Reference Consortium. ${ }^{24}$ All variants with IMPUTE2 info $<0.7$ were removed. After imputing the genotypes using each reference panel separately, we combined the results selecting the variants with a higher info score when they were present in more than one reference panel. The SNP dosage from IMPUTE2 was transformed to binary PLINK format by using the '-hard-callthreshold 0.1' flag from PLINK. The final core set had approximately 15 million variants with $\mathrm{MAF}>0.001$ and 9.5 million 
variants with $\mathrm{MAF}>0.01$. Imputation was performed at the Barcelona Supercomputing Center.

\section{Heritability}

Trait SNP heritability $\left(\mathrm{h}_{\text {SNP }}^{2}\right)$ was estimated from SNP/INDEL array/imputed data with the GREML-LDMS method implemented in the GCTA software. ${ }^{25}$ Since this method is relatively unbiased regarding MAF and linkage disequilibrium (LD) parameters, we considered autosomal variants with MAF $>0.001$ (15 060719 SNPs) to avoid under/overestimation of heritability due to the relatively small sample analysed in the core study. Cryptic relatedness of distant relatives was also considered, and individuals whose relatedness in the genetic relationship matrix was $>0.025$ were discarded $(n=4717)$. Population stratification was controlled in the linear mixed model using the first 20 principal components of the PCA derived from population genetic structure analysis of the GCAT. Gender and age were also included as covariates in the model. The $\mathrm{h}_{\text {SNP }}^{2}$ CIs were calculated by using FIESTA. ${ }^{26}$

\section{Single-trait genome-wide association analysis}

We performed independent GWAs analyses for 205 selected traits (61 continuous and 144 binary). A total of 9499600 SNPs with MAF>0.01 were considered for this purpose. Linear regression models for continuous traits were assessed with PLINK. ${ }^{27}$ For binary traits, given the unbalanced design of most of the traits considered, we used a scoring test with saddle point approximation included in the SPAtest R package. ${ }^{28}$ This approach compensates a slight loss of power with the inclusion of uncommon and rare conditions, without affecting robustness. All the models included the first 20 PCAs, age and gender as covariates. A PCA-mixed analysis was applied to approximate the number of independent traits ${ }^{29}$ (online supplementary figure S1). Based on these figures, Bonferroni correction for multiple traits was defined at $\mathrm{p}<5 \times 10^{-10}$ accounting for 100 independent traits explaining $80 \%$ of the phenome variability.

\section{Multitrait meta-analysis for correlated traits}

We applied a multitrait approach for the analysis of anthropometric traits (weight, height, body mass index (BMI) and waist and hip circumference) in a two-stage association study using individuals of British ancestry from the UK Biobank cohort $\left(\mathrm{N}=336\right.$ 107). ${ }^{30}$ Waist-to-hip ratio was excluded from this analysis due to its unavailability from the UK Biobank resource. UK Biobank summary-level statistics was calculated using linear regression models with the inferred gender and the first 10 PCAs as covariates, similarly to the model applied on GCAT data (see the URLs section). All SNPs with suggestive association $\mathrm{p}<1 \times 10^{-5}$ for any trait were retained from the GCAT GWAS analysis. Then, only SNPs intersecting with the UK Biobank resource were used for multitrait meta-analysis association testing in both samples, and $\mathrm{p}<5 \times 10^{-9}$ was considered significant. The multitrait association testing was based on the distribution of the sum of squares of the $\mathrm{z}$ scores which is insensitive to the direction of the scores. ${ }^{31}$ Briefly, let $Z=\left(z_{1}, z_{2}, \ldots, z_{k}\right)$ be the $z$ scores for a given SNP for $k$ phenotypes. The sum of squares of the z scores, $S_{s q}=\sum_{i=1}^{k} z_{i}^{2}$, can be approximated by the $\chi^{2}$ distribution $\left(\chi^{2}\right)$. Let $\Sigma$ be the covariance matrix of the genome-wide $\mathrm{z}$ scores from the phenotypes under analysis. And let $c_{i}$ be the eigenvalues of $\Sigma$, the distribution of $S_{s q}$ is well approximated by $a \chi_{d}^{2}+b$, where $a, b$ and $d$ depend on $c_{i}$. Then, we calculated the $\mathrm{p}$ value as: $p\left(\chi_{d}^{2}>\left(S_{s q}-b\right) / a\right)$. To estimate the covariance matrix of the correlated traits, we selected independent SNPs (LD pruning in PLINK “--indep-pairwise 505 0.2”) and filtered out SNPs with $\mid z$ scores $\mid>1.96$ to avoid possible bias in the estimation of $\Sigma$ because of the difference in sample size and association $p$ values in the GCAT-UK Biobank. A summary flow chart of the methods applied in this study is shown in figure 1.

\section{Polygenic risk score}

Genetic architecture was analysed by the polygenic risk score (PRS). Polygenic risk score software (PRSice) ${ }^{32}$ was used to predict the genetic variability of the identified loci for a given trait. PRSice plots the percentage of variance explained for a trait by using SNPs with different $\mathrm{p}$ value thresholds $\left(\mathrm{P}_{\mathrm{T}}\right)$ (online supplementary figure S2). Here, we considered $\mathrm{P}_{\mathrm{T}}=0.05$.

\section{URLS}

GCAT study, http://genomesforlife.com;

National Human Genome Research Institute GWAS Catalog, http://www.genome.gov/gwastudies/ (gwas_catalog_v1.0-associations_e91_r2018-02-06);

1000 Genomes Project http://www.internationalgenome.org/ (phase 3, v5a.20130502);

Genome of Netherland http:/www.nlgenome.nl/ (Release 5.4);

UK10K https://www.uk10k.org/ (Release 2012-06-02, updated on 15 Feb 2016);

Haplotype Reference Consortium http://www.haplotypereference-consortium.org/(Release 1.1);

UKBiobank GWAS Results; https://sites.google.com/ broadinstitute. org/ukbbgwasresults/ home? authuser $=0$, (Manifest20170915);

GTExportal, https://www.gtexportal.org/home/. (last data accession, Release V.7, dbGaP accession phs000424. v7. P2);

\section{RESULTS}

\section{Heritability estimates}

SNP heritability estimation $\left(\mathrm{h}^{2}{ }_{\mathrm{SNP}}\right)$ in the GCATcore study showed values ranging from $77 \%$ to $18 \%$, with height being the trait showing the strongest SNP contribution. The $\mathrm{h}^{2}{ }_{\text {SNP }}$ SE for most traits was high (near 10\%), with wide CIs, as expected by sample size. However, robustness of the analysis is supported by similar values to those reported elsewhere (see wide summary in Genomewide complex trait analysis, Wikipedia. The Free Encyclopedia, 2018). Statistically significant $h_{\text {SNP }}^{2}$ estimations for continuous and binary traits (cases $>500$ ) are shown in table 1. In particular, values for height: $\mathrm{h}_{\mathrm{SNP}}^{2}=0.77,95 \%$ CI0.56 to 0.94 and BMI: $\mathrm{h}_{\mathrm{SNP}}^{2}=0.38$, 95\% CI0.20 to 0.59 were identical to the maxima achieved in other European populations, using comparable genomic approaches. Besides the anthropometric traits, the Fitzpatrick's phototype score, a numerical classification schema for human skin colour to measure the response of different types of skin to ultraviolet light, had a high genetic consistency in our sample $\left(\mathrm{h}^{2}{ }_{\mathrm{SNP}}=0.63,95 \%\right.$ CI 0.4 to 0.8 ), and concordantly all related categories (eye colour, hair colour, freckling and skin sensitivity) showed high heritability $\left(\mathrm{h}_{\mathrm{SNP}}^{2}>0.3\right)$. It is worth noting that skin colour had the lowest value $\left(\mathrm{h}^{2}{ }_{\mathrm{SNP}}=0.18,95 \%\right.$ CI 0.02 to 0.38$)$, which is in concordance with the blurred genetic architecture of skin colour. ${ }^{33}$ Interestingly, other non-biological traits showed relatively high values in our study. Educational level showed the third highest heritability value $\left(\mathrm{h}_{\mathrm{SNP}}^{2}=0.54,95 \%\right.$ CI 0.35 to 0.74$)$. Lower estimates have been observed in other Caucasian populations, but this could be explained by the fact that this estimate is for educational level as a categorical variable and not as binary (higher/lower). 


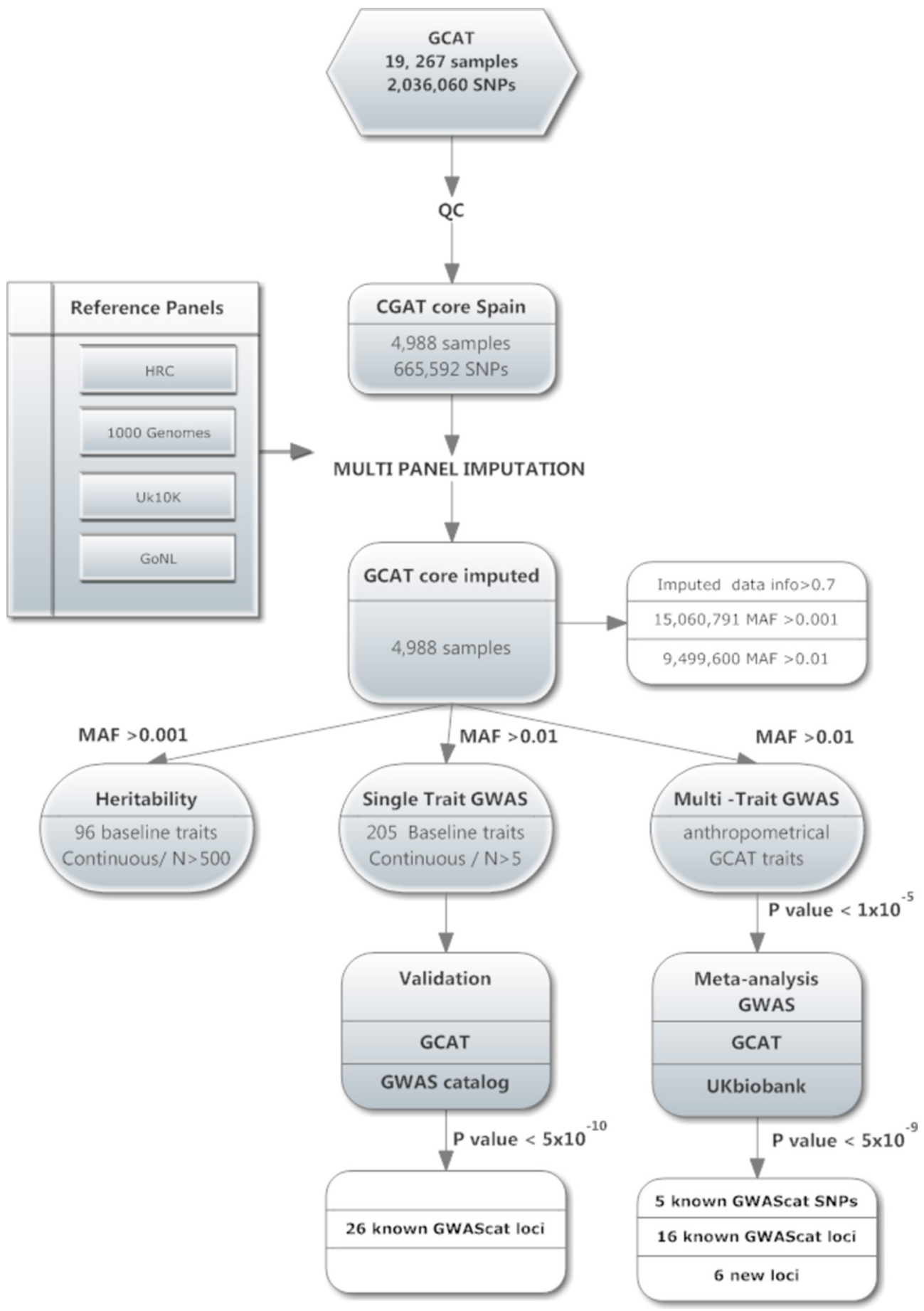

Figure 1 Flow chart of the methods and criteria used in this study. GCAT, Genomes For Life- Cohort Study of the Genomes of Catalonia; GWAS, genomewide association studies; MAF, minor allele frequency; QC, quality control.

Self-perceived health was similar to $\mathrm{h}^{2}$ SNP from recent data from a larger UK Biobank study, ${ }^{16}$ with values around $20 \%\left(\mathrm{~h}^{2}{ }_{\mathrm{SNP}}=0.22\right.$, 95\% CI 0.04 to 0.43 ).

\section{Phenome analysis}

GWAS identified 6820 associations in 1785 SNPs with genome-wide significance threshold $\mathrm{p}<5 \times 10^{-8}$ and 29343 associations with a suggestive association $\mathrm{p}<1 \times 10^{-5}$. Here, we report 26 genomewide association hits identified in our study which confirm results previously identified in other European ancestry samples (GWAS Catalog database (release V.1.0, e90, 27 September 2017)). ${ }^{4}$ In table 2, we show the SNP associations with the minimum $\mathrm{p}$ value for each locus, the remaining SNPs are shown in online Supplementary file 5 . Five genes associated with pigmentary traits were identified in the analysis with highly significant SNP associations: SLC45A2 (rs16891982, $\beta=-0.546, \mathrm{SE}=0.021, \mathrm{p}=2.2 \times 10^{-130}$ ), IRF4 (rs12203592, $\left.\beta=1.915, \mathrm{SE}=0.118, \mathrm{p}=2.8 \times 10^{-57}\right)$, HERC2 (rs1667394, $\beta=-0.608, \quad \mathrm{SE}=0.02, \quad \mathrm{p}=2.8 \times 10^{-176}$ ), OCA2 (rs11855019, $\left.\beta=-0.548, \mathrm{SE}=0.022, \mathrm{p}=2.4 \times 10^{-121}\right)$ and $M C 1 R$

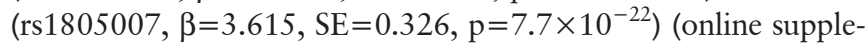
mentary figure S3). These genes are involved in the regulation and distribution of melanin pigmentation or enzymes involved in melanogenesis itself within the melanocyte cells present in the skin, hair and eyes in Caucasian populations. ${ }^{33-35}$ Pigmentary traits (mainly 
Table $1 \quad \mathrm{~h}_{\text {SNP }}^{2}$ of the analysed traits with $\mathrm{h}_{\text {SNP }}^{2}>0, \mathrm{SE}<0.12, \mathrm{p}<0.05$ and $n_{\mathrm{b}}>500$

\begin{tabular}{|c|c|c|c|c|c|c|c|c|c|}
\hline Questionnaire-section & Description & Trait name & h2SNP & SE & $95 \% \mathrm{Cl}$ & $P$ values & $\mathbf{n}$ & $n_{b}$ & NA \\
\hline $\begin{array}{l}\text { Anthropometric and blood } \\
\text { pressure }\end{array}$ & Height & height_c & 0.77 & 0.11 & 0.56 to 0.94 & $2 \times 10^{-12}$ & 4717 & - & 0 \\
\hline Other habits & Phototype score & phototype_score & 0.63 & 0.11 & 0.4 to 0.8 & $3.7 \times 10^{-9}$ & 4664 & - & 56 \\
\hline $\begin{array}{l}\text { Demographic and } \\
\text { socioeconomic }\end{array}$ & Educational level & education & 0.54 & 0.10 & 0.35 to 0.74 & $1.1 \times 10^{-8}$ & 4698 & - & 19 \\
\hline Other habits & Fitzpatrick phototype score & phototype_score categorical & 0.52 & 0.11 & 0.29 to 0.74 & $6.0 \times 10^{-7}$ & 4664 & - & 56 \\
\hline Other habits & Eye colour phototype score & eye_color_phototype_score & 0.48 & 0.11 & 0.27 to 0.68 & $7.1 \times 10^{-6}$ & 4716 & - & 1 \\
\hline Other habits & Freckling (has freckles) & freckling_binary & 0.47 & 0.11 & 0.26 to 0.68 & $8.1 \times 10^{-6}$ & 4713 & 590 & 4 \\
\hline Other habits & Hair colour phototype score & hair_color_phototype_score & 0.46 & 0.11 & 0.26 to 0.68 & $6.7 \times 10^{-6}$ & 4709 & - & 9 \\
\hline Other habits & Eye colour & eye_color & 0.44 & 0.11 & 0.24 to 0.65 & $3.4 \times 10^{-5}$ & 4716 & - & 1 \\
\hline Other habits & Hair colour & hair_color & 0.41 & 0.11 & 0.21 to 0.63 & $4.1 \times 10^{-5}$ & 4709 & - & 9 \\
\hline Other habits & Hair colour (black) & hair_color_black & 0.39 & 0.11 & 0.22 to 0.59 & 0.00018 & 4709 & 952 & 9 \\
\hline $\begin{array}{l}\text { Anthropometric and blood } \\
\text { pressure }\end{array}$ & BMI $\left(\mathrm{kg} / \mathrm{m}^{2}\right)$ & bmi & 0.38 & 0.11 & 0.2 to 0.59 & 0.00013 & 4717 & - & 0 \\
\hline $\begin{array}{l}\text { Anthropometric and blood } \\
\text { pressure }\end{array}$ & Weight & weight_c & 0.37 & 0.11 & 0.19 to 0.57 & 0.00016 & 4717 & - & 0 \\
\hline Tobacco consumption & Smoking habit & smoking_habit & 0.36 & 0.11 & 0.19 to 0.58 & 0.00037 & 4717 & - & 0 \\
\hline Tobacco consumption & Smoking packs per day & smoking_packs & 0.35 & 0.11 & 0.17 to 0.55 & 0.00082 & 4717 & - & 0 \\
\hline Other habits & Skin sensitivity to sun & skin_sensitivity_to_sun & 0.33 & 0.11 & 0.15 to 0.52 & 0.0011 & 4714 & - & 3 \\
\hline $\begin{array}{l}\text { Anthropometric and blood } \\
\text { pressure }\end{array}$ & Hip circumference & hip_c & 0.31 & 0.11 & 0.15 to 0.51 & 0.0011 & 4717 & - & 0 \\
\hline Occupation & Working status (active) & working_status_active & 0.31 & 0.11 & 0.13 to 0.54 & 0.0014 & 4696 & 1570 & 23 \\
\hline Other habits & $\begin{array}{l}\text { Skin sensitivity to sun phototype } \\
\text { score }\end{array}$ & $\begin{array}{l}\text { skin_sensitivity_to_sun_ } \\
\text { phototype_score }\end{array}$ & 0.30 & 0.11 & 0.12 to 0.51 & 0.0022 & 4714 & - & 3 \\
\hline $\begin{array}{l}\text { Anthropometric and blood } \\
\text { pressure }\end{array}$ & BMI obesity & bmi_who_obesity & 0.29 & 0.11 & 0.12 to 0.51 & 0.0031 & 4717 & 1388 & 0 \\
\hline Physical activity & Sleep duration & sleep_duration & 0.29 & 0.11 & 0.1 to 0.49 & 0.0033 & 4645 & - & 79 \\
\hline Other habits & Freckling & freckling & 0.28 & 0.11 & 0.11 to 0.5 & 0.0043 & 4713 & - & 4 \\
\hline Medical history & Mental health (MHI-5) & sadness & 0.26 & 0.11 & 0.09 to 0.48 & 0.0053 & 4717 & 504 & 0 \\
\hline Occupation & Working last year & working_last_year & 0.26 & 0.11 & 0.09 to 0.47 & 0.0065 & 4685 & 1190 & 32 \\
\hline Other habits & Freckling phototype score & freckling_phototype_score & 0.26 & 0.11 & 0.09 to 0.46 & 0.0076 & 4713 & - & 4 \\
\hline Other habits & Eye colour (dark) & eye_color_dark & 0.25 & 0.11 & 0.07 to 0.47 & 0.012 & 4716 & 1192 & 1 \\
\hline Other habits & Hair colour (brown) & hair_color_brown & 0.24 & 0.11 & 0.07 to 0.45 & 0.012 & 4709 & 1229 & 9 \\
\hline $\begin{array}{l}\text { Anthropometric and blood } \\
\text { pressure }\end{array}$ & Waist circumference & waist_c & 0.24 & 0.11 & 0.06 to 0.44 & 0.01 & 4717 & - & 0 \\
\hline $\begin{array}{l}\text { Anthropometric and blood } \\
\text { pressure }\end{array}$ & Waist-to-hip ratio WHO categories & whr_who & 0.23 & 0.11 & 0.05 to 0.45 & 0.016 & 4717 & - & 0 \\
\hline Medical history & Self-perceived health & self_perceived_health & 0.22 & 0.11 & 0.04 to 0.43 & 0.024 & 4715 & - & 2 \\
\hline Tobacco consumption & Smoking status (ever smoked) & smoking_status & 0.21 & 0.11 & 0.02 to 0.42 & 0.026 & 4522 & 1828 & 204 \\
\hline Alcohol consumption & Current alcohol consumption & alcohol_actual & 0.20 & 0.11 & 0.03 to 0.4 & 0.031 & 4713 & 3670 & 4 \\
\hline Diet & Predimed score & predimed_score & 0.20 & 0.11 & 0.03 to 0.41 & 0.031 & 4627 & - & 95 \\
\hline Women's health & No of female children & offspring_female & 0.19 & 0.11 & 0.02 to 0.4 & 0.028 & 4717 & - & 0 \\
\hline $\begin{array}{l}\text { Anthropometric and blood } \\
\text { pressure }\end{array}$ & Waist-to-hip ratio obesity & whr_who_obesity & 0.19 & 0.11 & 0.04 to 0.39 & 0.036 & 4717 & 1512 & 0 \\
\hline Women's health & No of male children & offspring_male & 0.19 & 0.11 & 0.02 to 0.41 & 0.036 & 4717 & - & 0 \\
\hline Medical history & Self-perceived health (bad) & self_perceived_health_binary & 0.18 & 0.11 & 0.02 to 0.4 & 0.047 & 4715 & 629 & 2 \\
\hline Medical history & $\begin{array}{l}\text { Certain adverse effects not } \\
\text { classified elsewhere }\end{array}$ & icd9_code3_995 & 0.18 & 0.11 & 0.01 to 0.37 & 0.042 & 4717 & 775 & 0 \\
\hline $\begin{array}{l}\text { Demographic and } \\
\text { socioeconomic }\end{array}$ & Civil status (ever been married) & civil_status_ever_married & 0.18 & 0.11 & 0.01 to 0.38 & 0.04 & 4703 & 523 & 15 \\
\hline Other habits & Skin colour phototype score & skin_color_phototype_score & 0.18 & 0.11 & 0.02 to 0.38 & 0.047 & 4714 & - & 3 \\
\hline
\end{tabular}

BMI, body mass index; $\mathrm{h}_{\text {SNP' }}^{2}$ SNP heritability estimation; MHI-5, Mental Health Inventory 5-item questionnaire; $n_{\mathrm{b}^{\prime}}$ sample size of the minor category in binary traits; $c$ for

Weight_c, height_c, hip_c and waist_c mean calculated-imputed variable.

the red hair colour phenotype) are related to the defensive capacity of the skin in response to sun exposure (UV-induced skin tanning or sun burning), and it has been established as a risk factor for sun-induced cancers (both melanoma and non-melanocytic skin cancers). ${ }^{36}$ Other GWAS hits from the phenome-wide analysis validated previously reported findings in CCDC141-LOC105373766 $\left(\right.$ rs79146658, $\left.\beta=2.359, \quad \mathrm{SE}=0.374, \quad \mathrm{p}=3.4 \times 10^{-10}\right), \quad S M A R-$ CA4-LDLR (rs10412048, $\beta=-0.5, S E=0.079, \mathrm{p}=3.2 \times 10^{-10}$; rs6511720, $\left.\beta=-0.493, \mathrm{SE}=0.08, \mathrm{p}=9.4 \times 10^{-10}\right)$ and LINC01432 (rs1160312, $\beta=0.193, \mathrm{SE}=0.03, \mathrm{p}=1.9 \times 10^{-9}$ ) loci, related with cardiovascular risk (heart_rate), hyperlipidaemia (icd9_code3_272) and male pattern baldness (hair_loss_40), respectively (see table 2). 


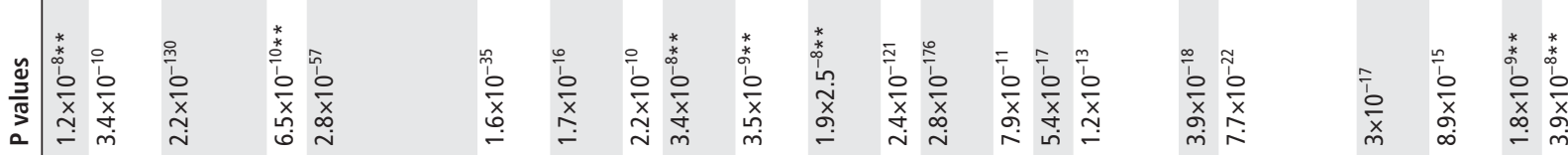

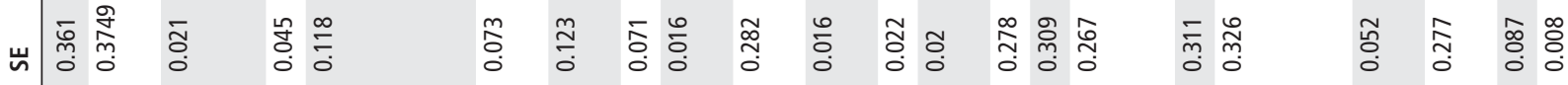

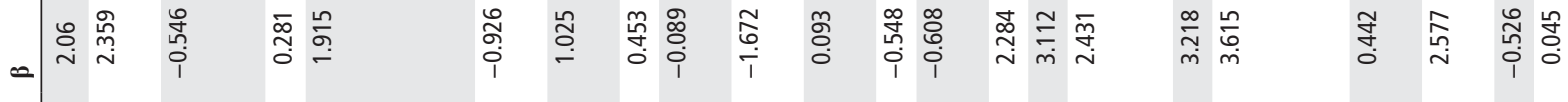

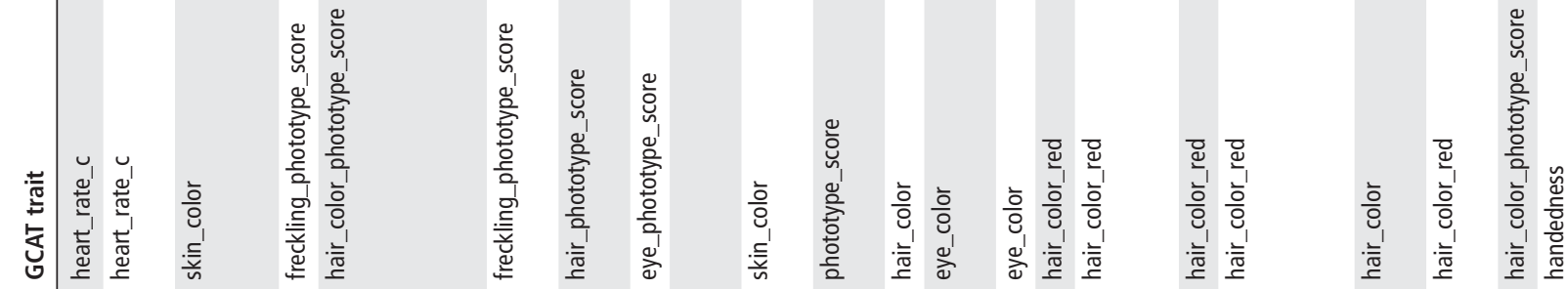

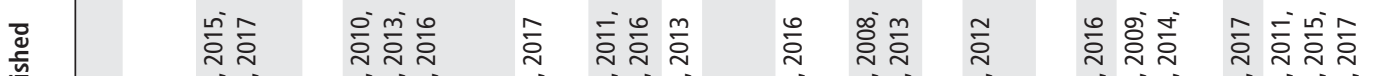

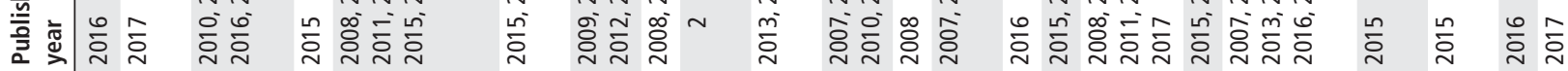
竧

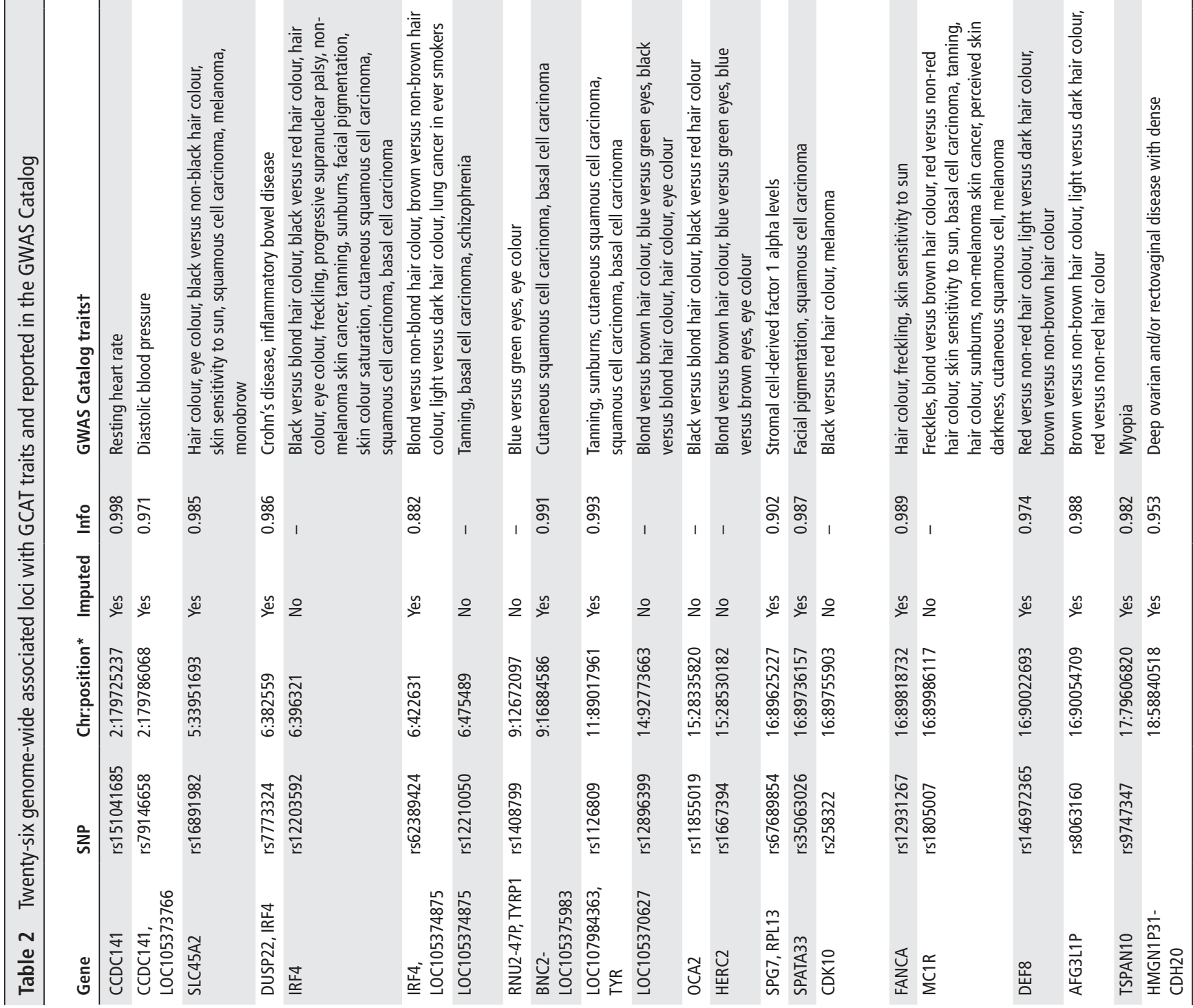




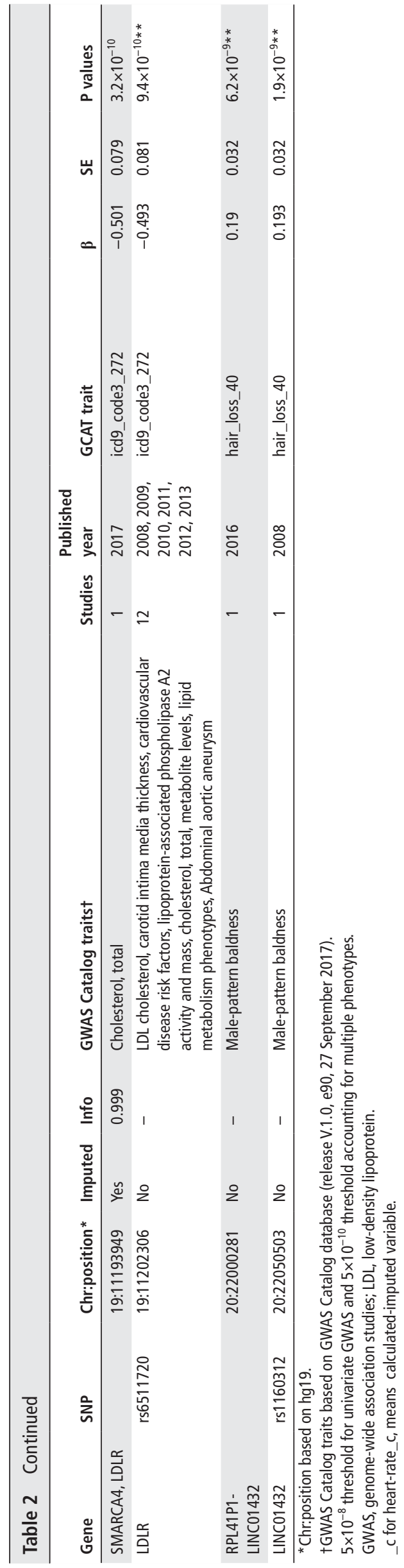

Multitrait meta-analysis of anthropometric traits

Anthropometric traits had a high heritability in our sample (height $=77 \%, \quad \mathrm{BMI}=38 \%$, weight $=37 \%$, hip circumference $=31 \%$ and waist circumference $=24 \%$ ), and all were highly correlated (online supplementary figure S1). In the first stage, from single-trait GWAS, we retained 606 SNPs with suggestive association $\left(\mathrm{p}<1 \times 10^{-5}\right)$ (see figure 2$)$. None of them reached the genomewide significance threshold. In the second stage, we analysed those 476 SNPs that intersected with the UK Biobank cohort dataset. Multitrait meta-analysis identified 111 SNPs in 27 independent loci with $p<5 \times 10^{-9}$ (online Supplementary file 7). Table 3 shows the SNPs with the highest significance for each independent loci and the univariate summary statistics of the anthropometric traits in both cohorts.

We estimated the covariance matrix $(\Sigma)$ for each dataset (GCAT, UK Biobank and GCAT + UK Biobank). Then, as described in the Materials and methods section, we selected those independent SNPs with $\mid z$ scores $\mid<1.96$, resulting in 765646,630890 and 535860 being considered for the $\Sigma$ estimation. Eigenvalues of $\Sigma$ showed d=1.36, 1.4 and 2.72 values. Covariance matrices were similar in both GCAT and UK Biobank (online supplementary tables S4 and S5). One degree of freedom (GCAT and UK Biobank) and three (GCAT + UK Biobank) of the ${ }^{2}$ distribution were considered for multitrait analysis. We identified 27 independent multitrait loci associated in GCAT and UK Biobank (table 3). We intersected these SNPs with the GWAS Catalog, and we found that 5 SNPs had previously been reported in multiple GWAS, 16 loci were reported considering a \pm 250000 base pair window from the identified SNP and 6 were new loci involving the following genes/SNPs: MAD1L1 (rs62444886, $\left.\mathrm{p}=2.3 \times 10^{-15}\right)$, PIK3R1 (rs12657050, $\mathrm{p}=2.8 \times 10^{-13} ; \mathrm{rs} 695166$, $\left.\mathrm{p}=8.4 \times 10^{-15}\right), \quad$ ZRANB2-AS2 (rs11205277, $\left.\mathrm{p}=1.4 \times 10^{-9}\right)$, EPHA7 (rs143547391, $\left.\mathrm{p}=6.5 \times 10^{-10}\right)$, CACUL1 (rs12414412, $\mathrm{p}=4 \times 10^{-13}$ ) and MAP3K9 (rs7151024, $\left.\mathrm{p}=5.7 \times 10^{-10}\right)$. Regarding DPYD, DPYD-IT1 (rs140281723), GABRG3-AS1 and GABRG3 (rs184405367) genes/SNPs, we did not replicate association in UK Biobank samples (UKmulti p $=0.035$ and 1 , respectively). The risk allele, frequency and functional annotation using the Variant Effect Predictor tool ${ }^{37}$ of identified variants are shown in online Supplementary file 9.

\section{Polygenic risk score}

The skin phototype association analysis identified five loci accounting for a high predictive value (PRS of 15.6\%) suggesting few main genes (oligogenic architecture) contributing to the phenotype (online supplementary figure S2). However, for anthropometric traits, 27 loci were identified in our cohort but with a lower PRS $(2.3 \%)$ suggesting a polygenic architecture with multiple genes and a high environmental impact. The newly identified loci only increased PRS slightly over the corresponding single-trait analysis $(2.2 \%$ to $2.5 \%, 2.3 \%$ to $3.3 \%, 2.2 \%$ to $3.5 \%$, $2.5 \%$ to $3.7 \%$ and $1.5 \%$ to $2.6 \%$ for height, weight, BMI and hip and waist circumference, respectively) pointing towards the multitrait approach as an effective screening strategy to identify new biomarkers.

\section{DISCUSSION}

Dissecting the architecture of common diseases should incorporate multitrait approaches to understand the phenome and its genetic aetiology, including pleiotropy and the co-occurrence of multiple morbidities, correlated traits and the diseasome as targets for genomic analysis. ${ }^{38}$ In this study, we used the GCAT study, a South-European Mediterranean population prospective 


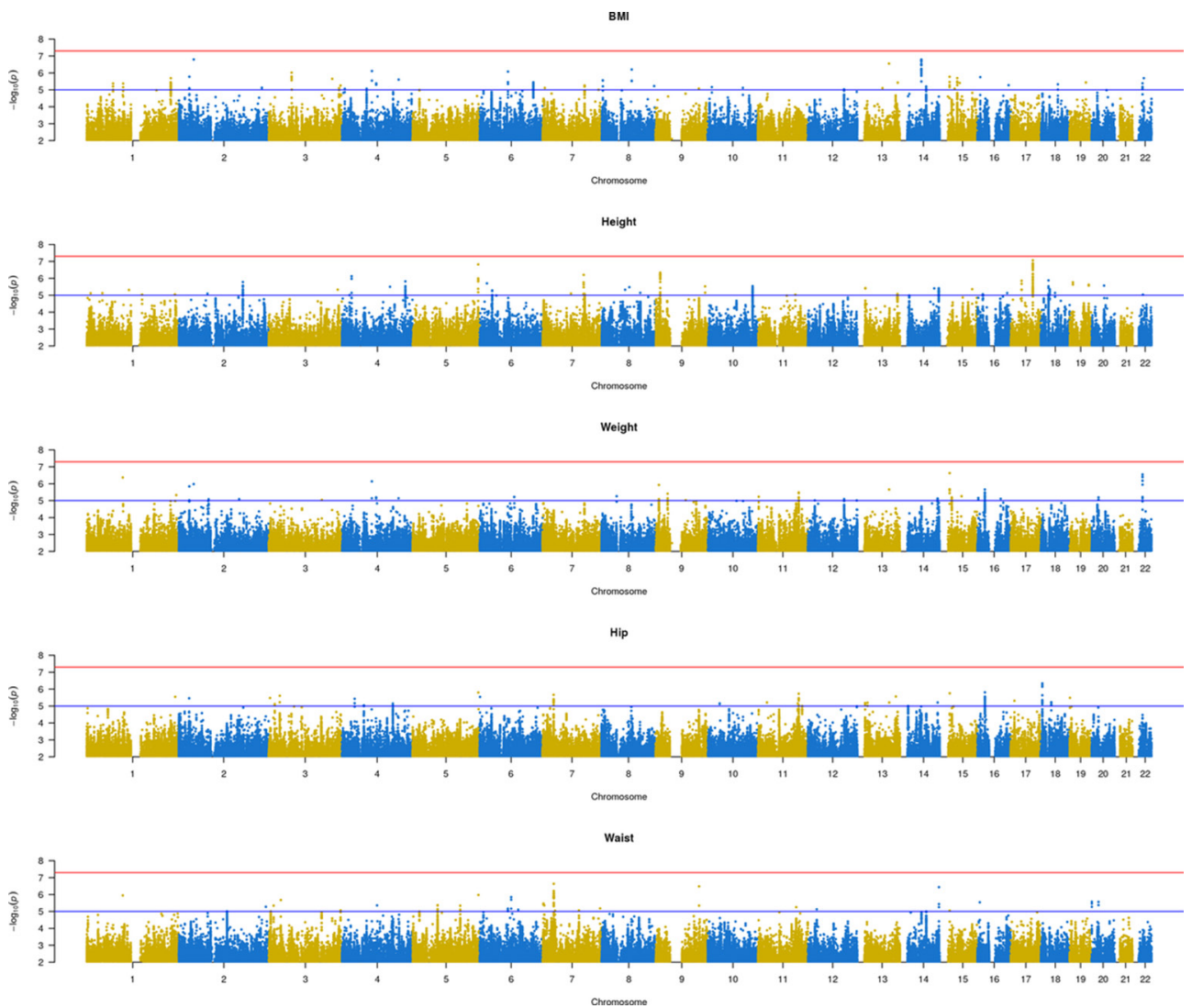

Figure 2 Manhattan plot of the anthropometric traits (BMI, height, weight and hip and waist circumference) from the GCAT. BMI, body mass index.

cohort to analyse the phenotypic variation attributable to genotype variability for 205 selected human traits (including diseases as well as biological, anthropometric and social features). Our results show that by considering genetic covariance matrices for interrelated traits, we increased the number of detected loci from six new loci for anthropometric traits, pointing to multitrait analysis as an effective strategy to gain statistical power to identify genetic association.

The relative importance of genetic and non-genetic factors varies across populations. Moreover, this is not constant in a population and changes with age. ${ }^{16}$ Here, we have reported heritability estimates on an adult population based on SNP data. In the present study, $\mathrm{h}_{\text {SNP }}^{2}$ values move in a wide range from $18 \%$ to $77 \%$, being anthropometric traits (height) and skin colour-related traits (Fitzpatrick's phototype score) the traits with the highest genetic determination. In our cohort, heritability of anthropometric traits, such as height and BMI, was likely estimated as a maximum, with negligible missed heritability when comparing with other reported estimates in similar populations ${ }^{39}$ and in the same way being the observed genetic variance only a small part of their complete variance (around 3\%). In the case of skin colour-related traits, the portion of the explained variance was larger, in accordance with a less complex polygenic nature of this trait, and fewer genes baring stronger predictive value (IRF4, HERC2, OCA2, MC1R and SLC45A2) (PRS=15.6\%). The variants identified in these loci associated with skin colour-related traits are functional and have been reported elsewhere in several studies. These differences in heritability and prediction values indicate a different genomic architecture, suggesting an exposure variation, the exposome, ${ }^{3}$ as a main actor for many polygenic traits. Higher estimates in self-perceived health heritability, and probably some other reported traits such as 'smoking_habits', 'smoking_packs', or 'sadness' (item from the Mental-Health Inventory 5-item questionnaire), reflect a pleiotropic effect ${ }^{40}$ with multiple associated loci. In this sense, a recent meta-analysis on subjective well-being revealed new loci accounting for a polygenic model of well-being status. ${ }^{41}$

Single-trait GWAS analysis identified a number of genetic variants associated with skin colour-related traits (online supplementary figure S3) and other complex traits (heart rate, hyperlipidaemia or male pattern baldness); whereas failed to identify specific variants associated with any single anthropometric trait (at the $\mathrm{p}<5 \times 10^{-8}$ threshold cut-off). However, we should observe that gender differences were not considered in this analysis even though it has been shown that genetic effects have a gender bias. ${ }^{42}$ Applying multitrait analyses of anthropometric traits, we identified 27 loci, six of which had not been reported previously; CALCUL1, ZRANB2-AS2, MAD1L1, EPHA7, PIK3R1 and MAP3K9. Owing to LD and the occurrence of all identified variants in non-coding regions (see online Supplementary file 9), we cannot be certain about the genes involved. Two out of six of the identified associated variants, in CALCUL1 and MAP3K9, are putative expression quantitative trait loci (eQTL) (see the URLs section). Three of the variants (ZRANB2-AS2chr1:71702511, EPHA7chr6:94075927 and MAP3K9chr14:71268446) are specific of the GCAT sample $\left(\mathrm{p}<5 \times 10^{-9}\right)$ (online Supplementary files $10,11, \mathrm{~S}, 12$ ) probably due to genetic background differences between populations (ie, LD patterns) or as an expression of a particular genetic contribution of the Mediterranean populations to these polygenic traits. Identified variants implicate genes with diverse functions, involved in several pathways and processes. Some of them are involved in growth, developmental or metabolic processes. 


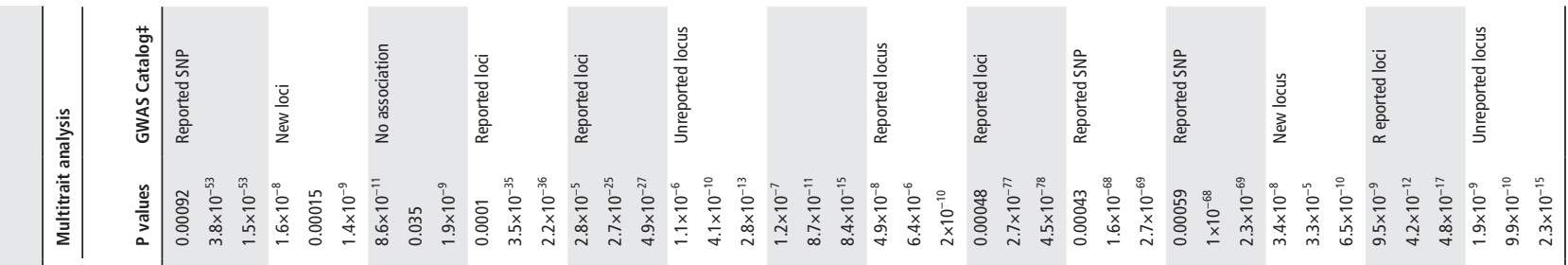

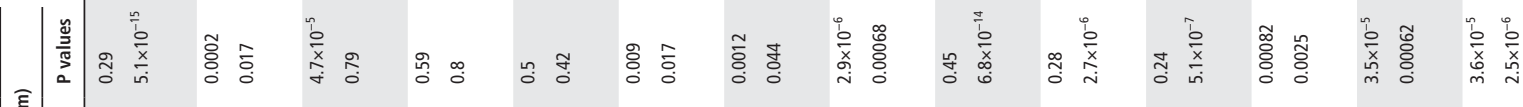

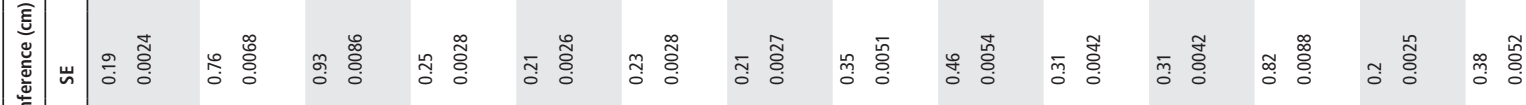

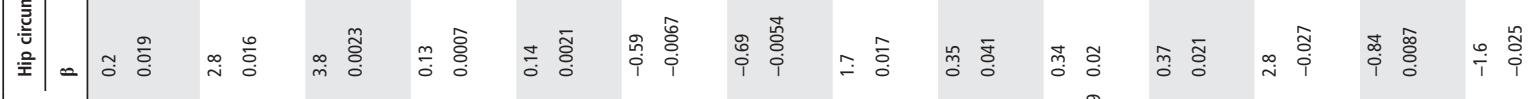

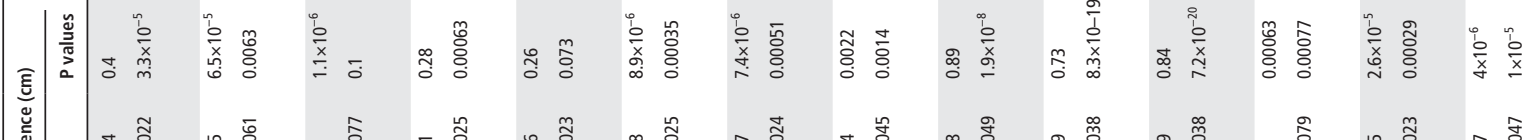

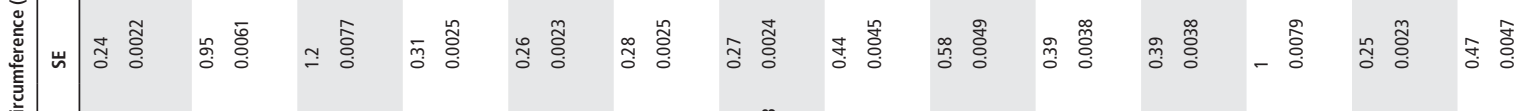

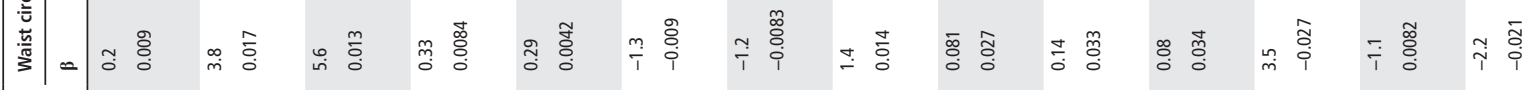

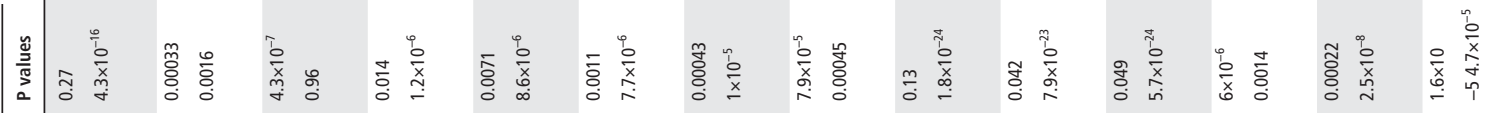

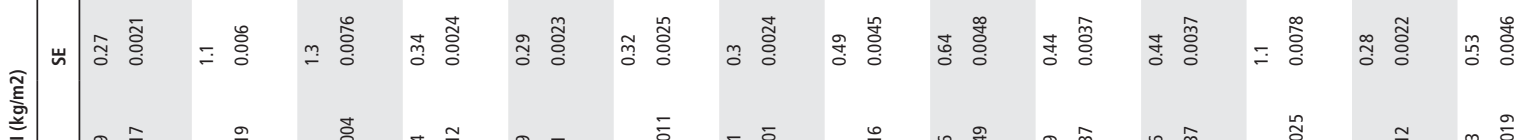

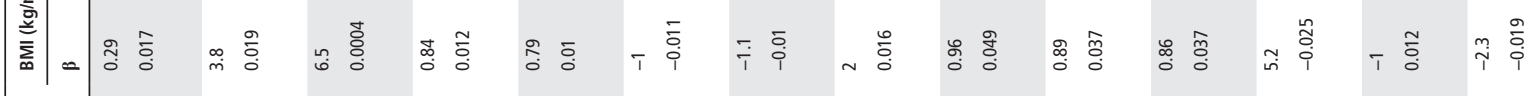

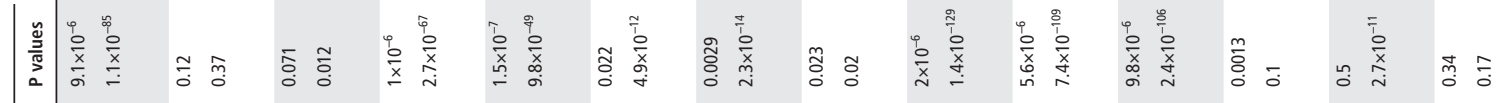

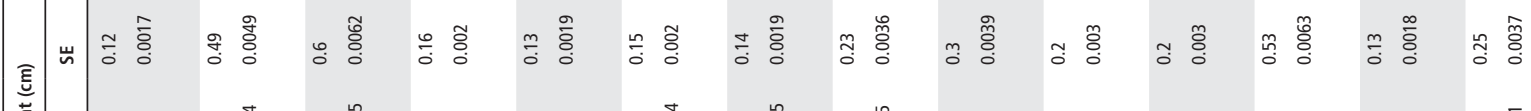

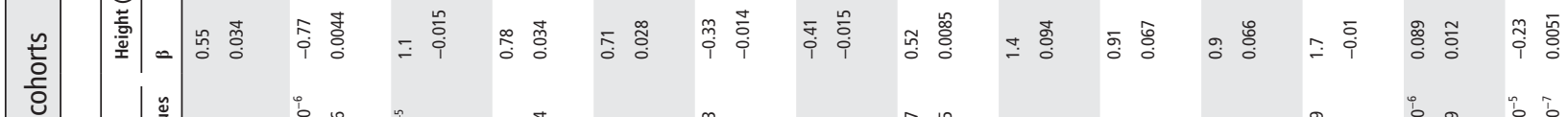

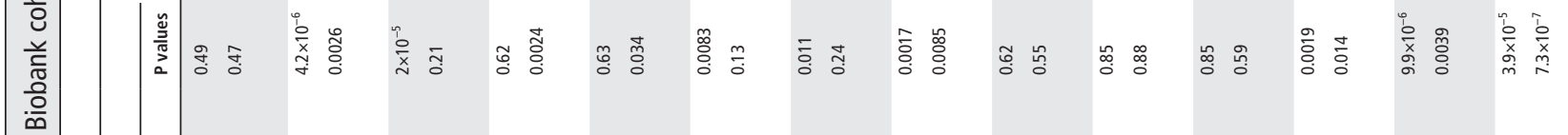

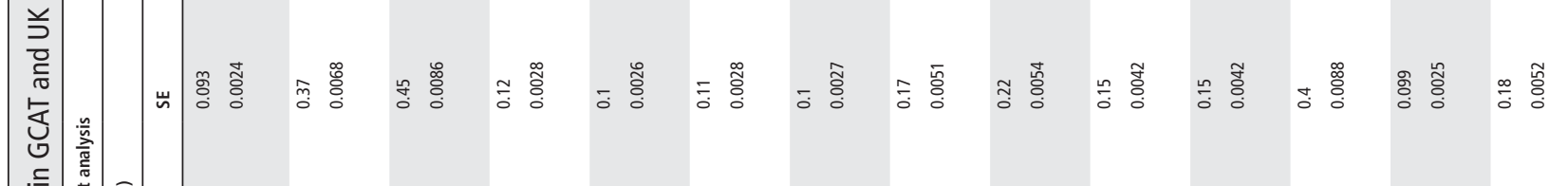

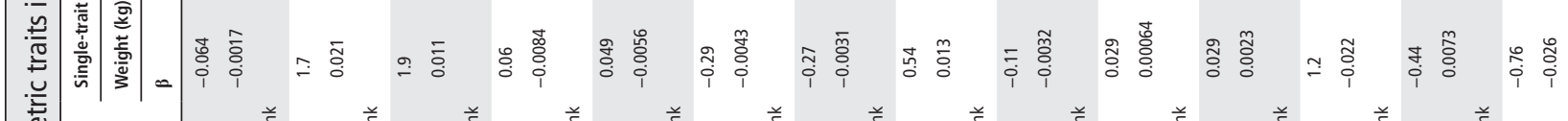

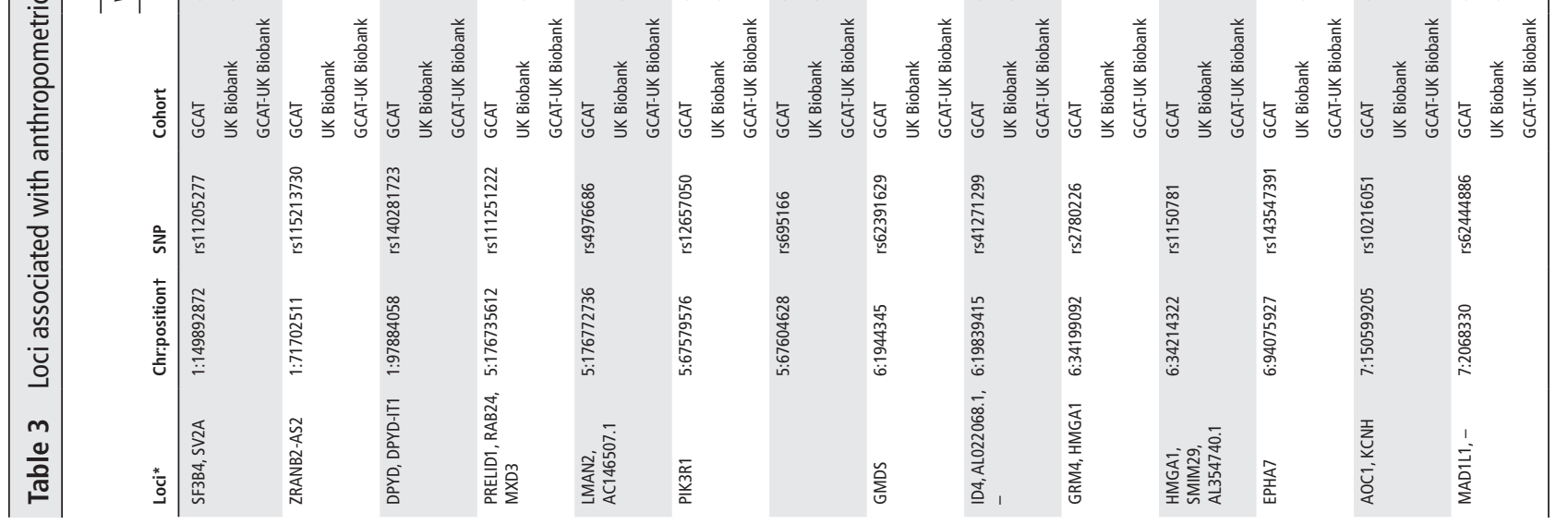




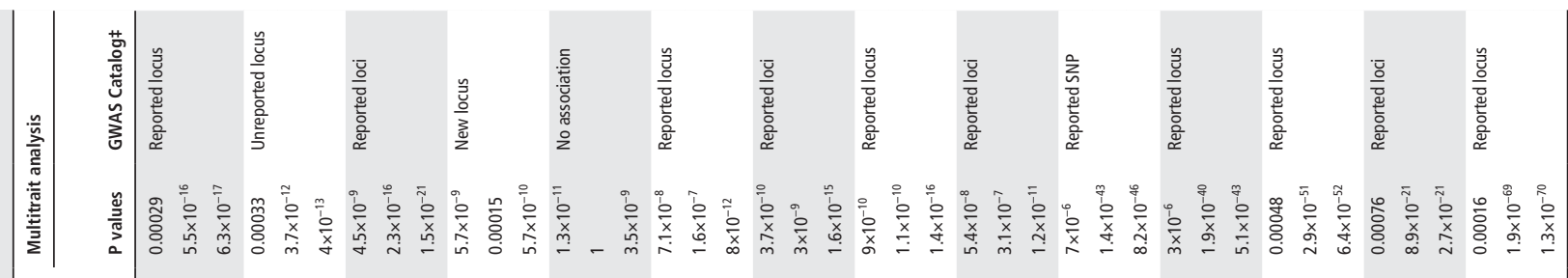

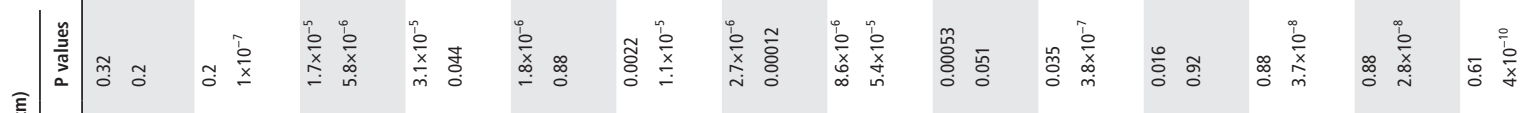

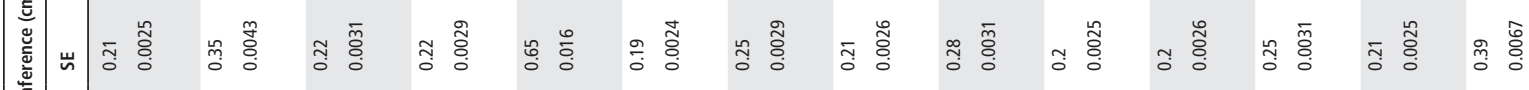

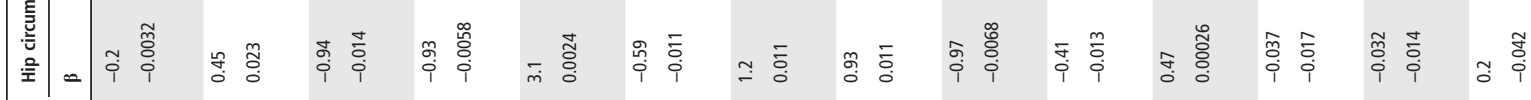

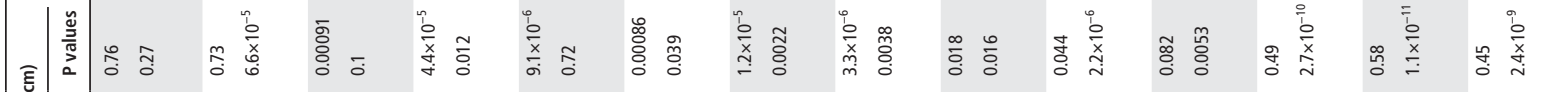

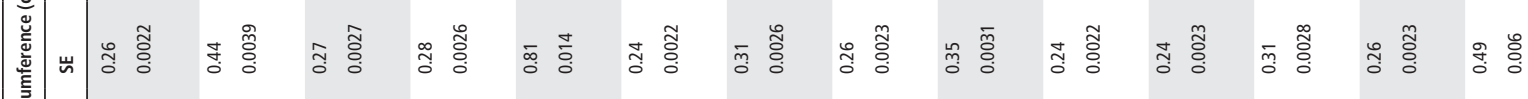

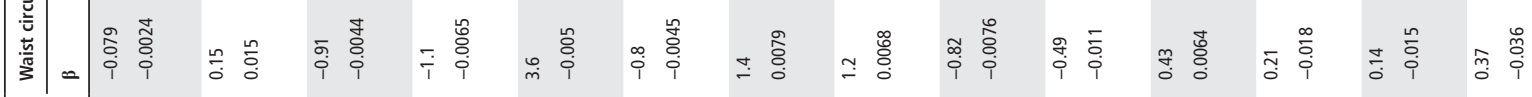

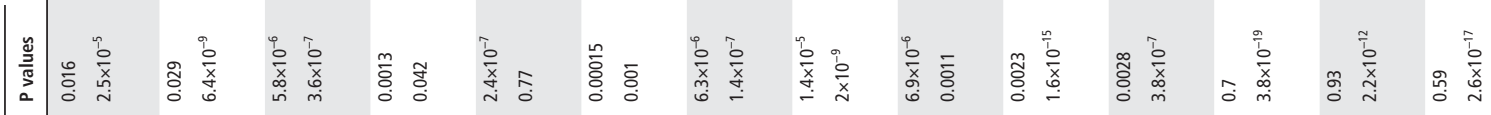

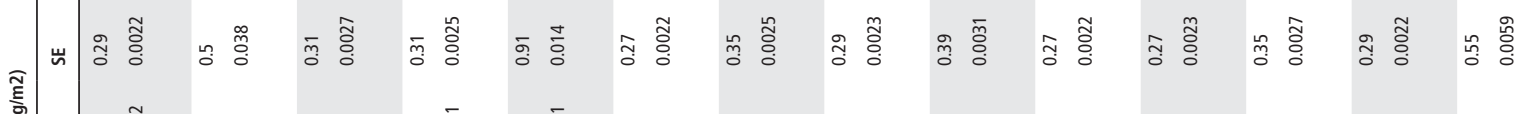

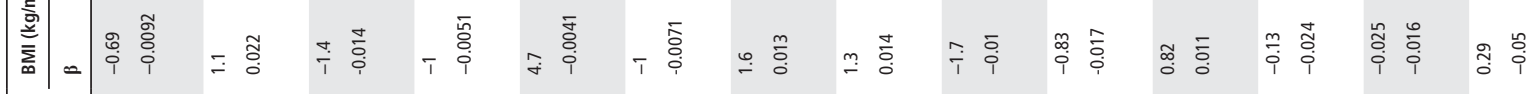

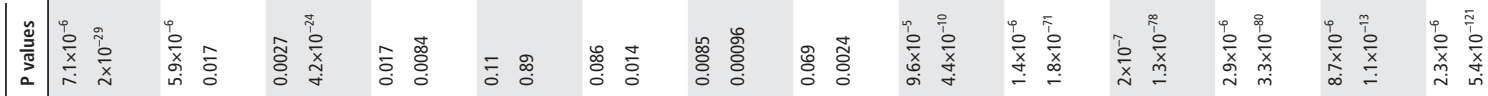

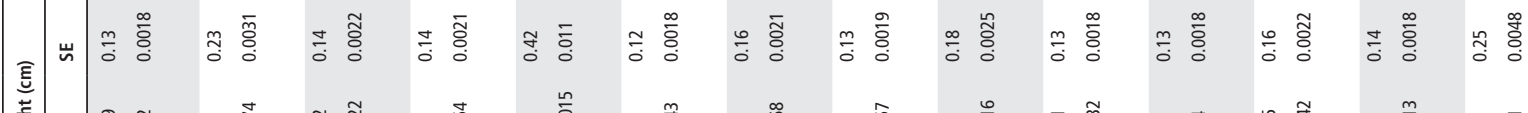

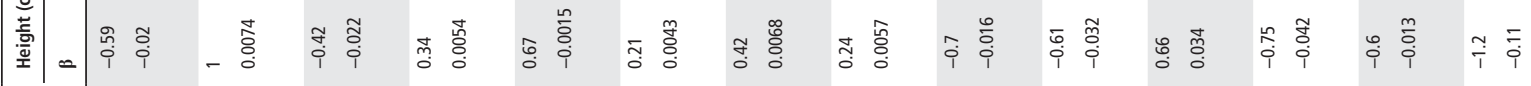

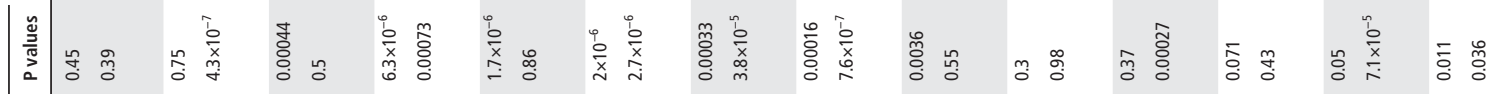
山

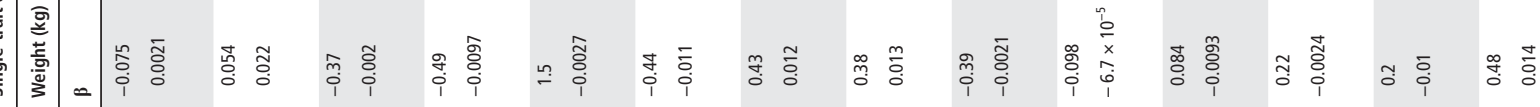

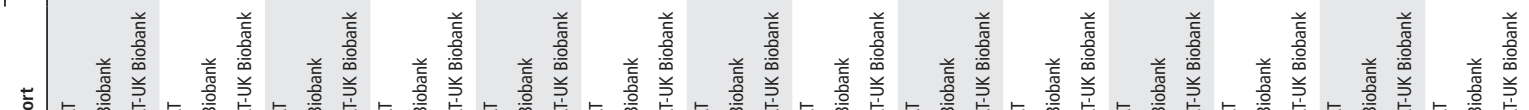

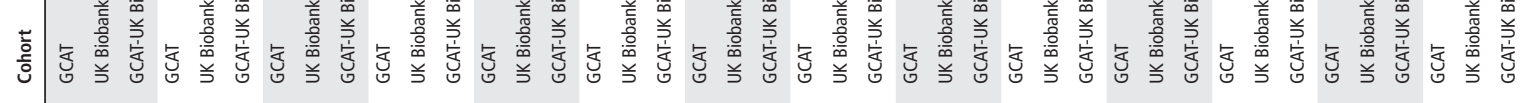

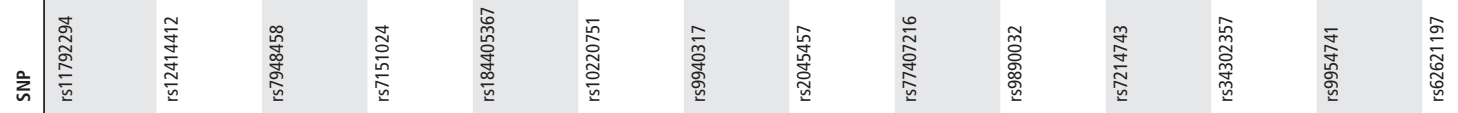

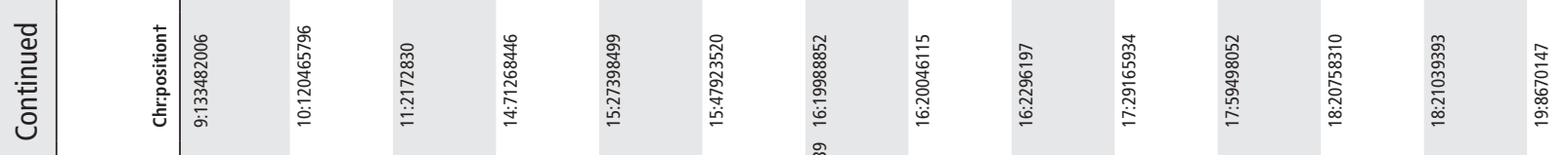

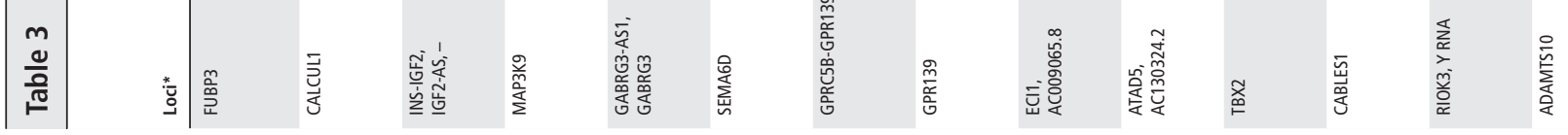




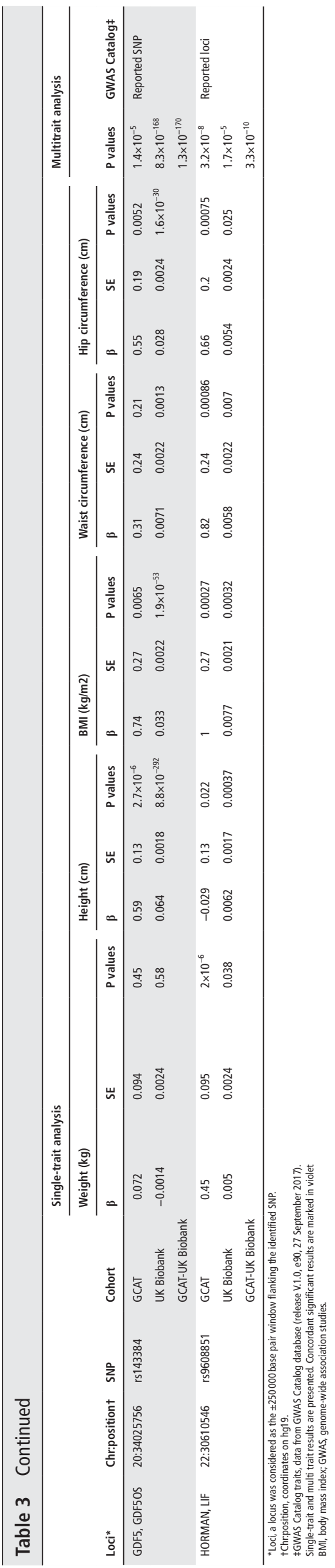

MAP3K9, mitogen-activated protein kinase 9, has been associated to some rare cancers (ie, retroperitoneum carcinoma and retroperitoneum neuroblastoma), and GWAS studies have identified variants associated with reasoning ability. ${ }^{43}$ Based on GTEx database (see URL section) we identified rs 7151024 as an eQTL, expressed in subcutaneous adipose tissue $\left(\mathrm{p}=1.4 \times 10^{-8}\right.$, eQTL effect size $\left.(\mathrm{es})=-0.38\right)$ that may affect fat distribution and anthropometric traits. ZRANB2-AS2 is a non-coding RNA, and GWAS studies have identified variants in ZRANB2-AS2 associated with facial morphology, ${ }^{44}$ and also with general cognitive function ${ }^{45}$ traits which are genetically correlated with a wide range of physical variables. EPHA7 belongs to the ephrin receptor subfamily of protein-tyrosine kinase, implicated in mediating developmental events, particularly in the nervous system. EPHA7 has been implicated in neurodevelopment processes ${ }^{46}$ as well being as a tumour suppressor gene in cancer. ${ }^{47} \mathrm{CACUL} 1, \mathrm{CDK} 2$-associated cullin domain 1 , is a cell cycle-dependent kinase binding protein capable of promoting cell progression. In the GWAS Catalog, any of the anthropometric traits analysed here have been associated with variants in CACUL1 (online Supplementary file 13). However, the associated rs12414412, reported as an eQTL expressed in skeletal muscle $\left(\mathrm{p}=1.4 \times 10^{-7}\right.$, eQTL es $=-0.31$ ), may affect body constitution. CACUL1 suppresses androgen receptor (AR) transcriptional activity, impairing LSD-mediated activation of the $\mathrm{AR},{ }^{48}$ whose genetic variation is associated with longitudinal height in young boys. ${ }^{49} M A D 1 L 1$, mitotic arrest deficient 1 -like protein 1 , is a component of the mitotic spindle-assembly checkpoint, and some cancers (prostate and gastric) have been associated to MAD1L1 dysfunction. ${ }^{50}$ Our study identified BMI, weight and hip and waist circumference single-trait association $\left(\mathrm{p}<10^{-5}\right)$ with the intronic variant $r s 62444886$ in the MAD1L1 locus, as well as a significant multitrait association in meta-analysis (table 3, online Supplementary file 14). GWAS analysis identified MAD1L1 as a susceptibility gene for bipolar disorder and schizophrenia, involved in reward system functions in healthy adults, ${ }^{51}$ but until now, no other study has identified it as a genetic contributor to weight. The higher prevalence of obesity and related disorders such as diabetes in schizophrenia patients could reflect a possible underlying common genetic contribution. In this sense, we observed also GWAS significant signals in INS-IGF2 (GCAT-UKmulti $\mathrm{p}=1.5 \times 10^{-21}$ ), an analogue of the INS gene (previously associated with diabetes type I and type II disorders). ${ }^{52}$ Additionally, epigenome-wide association studies in adults ${ }^{53}$ and children ${ }^{54}$ support a role for MAD1L1 in BMI-methylation association, with differentially methylated $\mathrm{CpG}$ patterns in CD4+ and CD8 + T cells between obese and non-obese women. PIK3R1, phosphoinositide-3-kinase regulatory subunit 1 , plays a role in the metabolic actions of insulin, and a mutation in this gene has been associated with insulin resistance. Moreover, common variants are associated with lower body fat percentage as well as the control of peripheral adipose tissue mobilisation. ${ }^{55}$ Genetic variation in the GWAS Catalog is also associated with cartilage thickness ${ }^{56}$ and mineral bone density, ${ }^{57}$ both related to anthropometric traits. Diseases associated with PIK3R1 include SHORT syndrome ${ }^{58}$ characterised by individuals with short stature and a restricted intrauterine growth, in addition to multiple anomalies. Our study identified the intronic variant (rs695166) associated with waist circumference association in single-trait analysis $\left(\mathrm{p}<10^{-6}\right)$, but not in the UKdataset, which associates with height $\left(\mathrm{p}=2.3 \times 10^{-14}\right)$. However, analysis of the UKBiobank data supported a similar peak profile overlapping the 
gene region (see online Supplementary file 12) and multitrait analysis association (GCAT-UK multi $\mathrm{p}=8.4 \times 10^{-15}$ ) (table 3 ).

Multiple approaches for multitrait analysis using GWAS data have been successfully applied in the research of genetically complex conditions using raw data or summary-level data statistics. Using raw data, Ferreira and Purcell ${ }^{11}$ used a test based on the Wilk's lambda derived from a canonical correlation analysis. Korte $e t a l^{13}$ implemented a mixed-model approach accounting for correlation structure and the kinship relatedness matrix. O'Reilly et $a l^{14}$ proposed an inverted regression model for each SNP as the response and all the traits as covariates. Regarding the use of GWAS summary-level data statistics, Cotsapas et al $l^{10}$ developed a statistic for cross-phenotype analysis based on an asymptotic ${ }^{2}$ distribution derived from $p$ values of the SNP associations. Zhu et al ${ }^{15}$ implemented CPASSOC that accounts for the genetic correlation structure of the traits and the sample size for each cohort. Kim et $a^{12}$ proposed an adaptive association test for multiple traits that uses Monte Carlo simulations to approximate its null distribution. Recently, Bayes factor approaches ${ }^{59}$ have been proposed for studying multitrait genetic associations. Here, for meta-analysis purposes, we chose the multitrait analysis described by Yang and Wang. ${ }^{31}$ This test, based on the ${ }^{2}$ distribution with ' $d$ ' $d f$, depends on the genetic covariance structure of the traits and considers the distribution of the sum square of the $\mathrm{z}$ scores which is insensitive to the heterogeneous effect of the SNP. Nevertheless, this approach doesn't allow allele effect estimation. In this sense, maximum likelihood methods have been recently proposed to deal with this limitation ${ }^{41}$ by accounting for different measures of the same phenotypic trait with different levels of heritability.

In complex diseases research, MRPs are the common observation in genome-wide association analysis of large cohorts, and over simplification of extreme phenotypes or the use of standardised phenotypes for meta-analysis reduces the power to detect the underlying genetic contribution to complex traits. As an alternative, multitrait analyses help to detect additional loci that are missing by applying a conventional meta-analysis. Our results highlight the potential value of data-driven multivariate phenotyping for genetic studies in large complex cohorts.

\section{Author affiliations \\ ${ }^{1}$ GenomesForLife-GCAT Lab Group, Program of Predictive and Personalized Medicine of Cancer (PMPPC), Germans Trias i Pujol Research Institute (IGTP), Crta. de Can Ruti, Badalona, Catalunya, Spain \\ ${ }^{2}$ Unit of Biomarkers and Susceptibility, Cancer Prevention and Control Program, Catalan Institute of Oncology (ICO), IDIBELL and CIBERESP, Barcelona, Spain ${ }^{3}$ High Content Genomics and Bioinformatics Unit, Program of Predictive and Personalized Medicine of Cancer (PMPPC), Germans Trias i Pujol Research Institute (IGTP), Badalona, Catalunya, Spain \\ ${ }^{4}$ Life Sciences - Computational Genomics, Barcelona Supercomputing Center (BSC- CNS), Joint BSC-CRG-IRB Research Program in Computational Biology, Barcelona, Spain \\ ${ }^{5}$ Programs in Metabolism and Medical \& Population Genetics, Broad Institute of Harvard and MIT, Cambridge, Massachusetts, US \\ ${ }^{6}$ Diabetes Unit and Center for Human Genetic Research, Massachusetts General Hospital, Boston, Massachusetts, US \\ ${ }^{7}$ Blood Division, Banc de Sang i Teixits, Barcelona, Spain \\ ${ }^{8}$ Cancer Genetics and Epigenetics Group, Program of Predictive and Personalized Medicine of Cancer (PMPPC), Germans Trias i Pujol Research Institute (IGTP), Badalona, Catalunya, Spain \\ ${ }^{9}$ ICREA, Catalan Institution for Research and Advanced Studies, Barcelona, Catalunya, Spain \\ ${ }^{10}$ Department of Clinical Sciences, Faculty of Medicine, University of Barcelona, Barcelona, Spain}

Correction notice This article has been corrected since it was published online first. JMM has been added to the authors list and to the 'Contributors' section.
Acknowledgements The authors thank all the GCAT participants and all BST members for generously helping with this research.

Contributors All authors contributed to the feedback of the manuscript and played an important role in implementing the study. IG-F, MP, VM and RdC conceived the study. IG-F and RdC planned the study. LP coordinated the cohort recruitment. AC, JV and XD prepared the samples. MO-S and XD curated the epidemiological data variables. DP, RP, LR, SA and LS conducted the genotyping. IG-F, DP and LS analysed the clustering analysis. IG-F, MG-M, JMM and DT conducted the imputation analysis. IG-F and RdC conducted and supervised the genetic analysis. IG-F, MO-S and RdC wrote the manuscript. RdC submitted and supervised the study.

Funding This work was supported in part by the Spanish Ministerio de Economía y Competitividad (MINECO) project ADE 10/00026, by the Catalan Departament de Salut and by the Departament d'Empresa i Coneixement de la Generalitat de Catalunya, the Agència de Gestió d'Estudis Universitaris i de Recerca (AGAUR) (SGR 1269, SGR 1589 and SGR 647). RdC is the recipient of a Ramon y Cajal grant (RYC2011-07822). The Project GCAT is coordinated by the Germans Trias i Pujol Research Institute (IGTP), in collaboration with the Catalan Institute of Oncology (ICO), and in partnership with the Blood and Tissue Bank of Catalonia (BST). IGTP is part of the CERCA Programme/Generalitat de Catalunya.

Competing interests None declared.

Patient consent Obtained.

Ethics approval http://www.ceicgermanstrias.cat/.

Provenance and peer review Not commissioned; externally peer reviewed.

Open access This is an open access article distributed in accordance with the Creative Commons Attribution Non Commercial (CC BY-NC 4.0) license, which permits others to distribute, remix, adapt, build upon this work non-commercially, and license their derivative works on different terms, provided the original work is properly cited, appropriate credit is given, any changes made indicated, and the use is non-commercial. See: http://creativecommons.org/licenses/by-nc/4.0/.

\section{REFERENCES}

1 Eurostat Statistics Explained. Mortality and life expectancy statistics, 2016. http://ec europa.eu/eurostat/statistics-explained/index.php/Mortality_and_life_expectancy_ statistics

2 Dawber TR, Meadors GF, Moore FE. Epidemiological approaches to heart disease: the Framingham Study. Am J Public Health Nations Health 1951;41:279-86.

3 Riboli E, Hunt KJ, Slimani N, Ferrari P, Norat T, Fahey M, Charrondière UR, Hémon B, Casagrande C, Vignat J, Overvad K, Tjønneland A, Clavel-Chapelon F, Thiébaut A, Wahrendorf J, Boeing H, Trichopoulos D, Trichopoulou A, Vineis P, Palli D, Bueno-DeMesquita HB, Peeters PH, Lund E, Engeset D, González CA, Barricarte A, Berglund G, Hallmans G, Day NE, Key TJ, Kaaks R, Saracci R. European Prospective Investigation into Cancer and Nutrition (EPIC): study populations and data collection. Public Health Nutr 2002;5:1113-24.

4 Welter D, MacArthur J, Morales J, Burdett T, Hall P, Junkins H, Klemm A, Flicek P, Manolio T, Hindorff L, Parkinson H. The NHGRI GWAS Catalog, a curated resource of SNP-trait associations. Nucleic Acids Res 2014;42:D1001-6.

5 Manolio TA, Collins FS, Cox NJ, Goldstein DB, Hindorff LA, Hunter DJ, McCarthy MI, Ramos EM, Cardon LR, Chakravarti A, Cho JH, Guttmacher AE, Kong A, Kruglyak L, Mardis E, Rotimi CN, Slatkin M, Valle D, Whittemore AS, Boehnke M, Clark AG, Eichler EE, Gibson G, Haines JL, Mackay TF, McCarroll SA, Visscher PM. Finding the missing heritability of complex diseases. Nature 2009:461:747-53.

6 Visscher PM, Wray NR, Zhang Q, Sklar P, McCarthy MI, Brown MA, Yang J. 10 Years of GWAS Discovery: Biology, Function, and Translation. Am J Hum Genet 2017; 101:5-22.

7 Boyle EA, Li YI, Pritchard JK. An Expanded View of Complex Traits: From Polygenic to Omnigenic. Cell 2017;169:1177-86.

8 Chakravarti A, Turner TN. Revealing rate-limiting steps in complex disease biology: The crucial importance of studying rare, extreme-phenotype families. Bioessays 2016;38:578-86

9 Freimer N, Sabatti C. The human phenome project. Nat Genet 2003;34:15-21.

10 Cotsapas C, Voight BF, Rossin E, Lage K, Neale BM, Wallace C, Abecasis GR, Barrett JC, Behrens T, Cho J, De Jager PL, Elder JT, Graham RR, Gregersen P, Klareskog L, Siminovitch KA, van Heel DA, Wijmenga C, Worthington J, Todd JA, Hafler DA, Rich SS, Daly MJ. FOCiS Network of Consortia. Pervasive sharing of genetic effects in autoimmune disease. PLoS Genet 2011;7:e1002254.

11 Ferreira MAR, Purcell SM. A multivariate test of association. Bioinformatics 2009;25:132-3.

12 Kim J, Bai Y, Pan W. An Adaptive Association Test for Multiple Phenotypes with GWAS Summary Statistics. Genet Epidemiol 2015;39:651-63.

13 Korte A, Vilhjálmsson BJ, Segura V, Platt A, Long Q, Nordborg M. A mixed-model approach for genome-wide association studies of correlated traits in structured populations. Nat Genet 2012;44:1066-71. 
14 O'Reilly PF, Hoggart CJ, Pomyen Y, Calboli FC, Elliott P, Jarvelin MR, Coin LJ. MultiPhen: joint model of multiple phenotypes can increase discovery in GWAS. PLoS One 2012;7:e34861.

15 Zhu X, Feng T, Tayo BO, Liang J, Young JH, Franceschini N, Smith JA, Yanek LR, Sun YV, Edwards TL, Chen W, Nalls M, Fox E, Sale M, Bottinger E, Rotimi C, Liu Y, McKnight B, Liu K, Arnett DK, Chakravati A, Cooper RS, Redline S; COGENT BP Consortium. Metaanalysis of correlated traits via summary statistics from GWASs with an application in hypertension. Am J Hum Genet 2015:96:21-36.

16 Ge T, Chen CY, Neale BM, Sabuncu MR, Smoller JW. Phenome-wide heritability analysis of the UK Biobank. PLoS Genet 2017;13:e1006711.

17 Muñoz M, Pong-Wong R, Canela-Xandri O, Rawlik K, Haley CS, Tenesa A. Evaluating the contribution of genetics and familial shared environment to common disease using the UK Biobank. Nat Genet 2016;48:980-3.

18 Obón-Santacana M, Vilardell M, Carreras A, Duran X, Velasco J, Galván-Femenía I, Alonso T, Puig L, Sumoy L, Duell EJ, Perucho M, Moreno V, de Cid R. GCAT|Genomes for life: a prospective cohort study of the genomes of Catalonia. BMJ Open 2018:8:e018324.

19 Liu Y, De A. Multiple Imputation by Fully Conditional Specification for Dealing with Missing Data in a Large Epidemiologic Study. Int I Stat Med Res 2015;4:287-95.

20 Howie B, Fuchsberger C, Stephens M, Marchini J, Abecasis GR. Fast and accurate genotype imputation in genome-wide association studies through pre-phasing. Nat Genet 2012;44:955-9.

21 Auton A, Brooks LD, Durbin RM, Garrison EP, Kang HM, Korbel JO, Marchini JL, McCarthy S, McVean GA, Abecasis GR; 1000 Genomes Project Consortium. A global reference for human genetic variation. Nature 2015;526:68-74.

22 Deelen P, Menelaou A, van Leeuwen EM, Kanterakis A, van Dijk F, Medina-Gomez C, Francioli LC, Hottenga JJ, Karssen LC, Estrada K, Kreiner-Møller E, Rivadeneira F, van Setten J, Gutierrez-Achury J, Westra HJ, Franke L, van Enckevort D, Dijkstra M, Byelas $H$, van Duijn CM, de Bakker PI, Wijmenga C, Swertz MA; Genome of Netherlands Consortium. Improved imputation quality of low-frequency and rare variants in European samples using the 'Genome of The Netherlands'. Eur I Hum Genet 2014:22:1321-6.

23 Huang J, Howie B, McCarthy S, Memari Y, Walter K, Min JL, Danecek P, Malerba G, Trabetti E, Zheng HF, Gambaro G, Richards JB, Durbin R, Timpson NJ, Marchini J, Soranzo N, Turki SA, Amuzu A, Anderson CA, Anney R, Antony D, Artigas MS, Ayub M, Bala S, Barrett JC, Barroso I, Beales P, Benn M, Bentham J, Bhattacharya S, Birney E, Blackwood D, Bobrow M, Bochukova E, Bolton PF, Bounds R, Boustred C, Breen G, Calissano M, Carss K, Casas JP, Chambers JC, Charlton R, Chatterjee K, Chen L, Ciampi A, Cirak S, Clapham P, Clement G, Coates G, Cocca M, Collier DA, Cosgrove C, Cox T, Craddock N, Crooks L, Curran S, Curtis D, Daly A, Inm D, Day-Williams A, Dedoussis G, Down T, Du Y, van DCM, Dunham I, Edkins S, Ekong R, Ellis P, Evans DM, Faroogi IS, Fitzpatrick DR, Flicek P, Floyd J, Foley AR, Franklin CS, Futema M, Gallagher L, Gasparini P, Gaunt TR, Geihs M, Geschwind D, Greenwood C, Griffin H, Grozeva D, Guo X, Guo X, Gurling H, Hart D, Hendricks AE, Holmans P, Huang L, Hubbard T, Humphries SE, Hurles ME, Hysi P, lotchkova V, Isaacs A, Jackson DK, Jamshidi Y, Johnson J, Joyce C, Karczewski KJ, Kaye J, Keane T, Kemp JP, Kennedy K, Kent A, Keogh J, Khawaja F, Kleber ME, van KM, Kolb-Kokocinski A, Kooner JS, Lachance G, Langenberg C, Langford C, Lawson D, Lee I, van LEM, Lek M, Li R, Li Y, Liang J, Lin H, Liu R, Lönnqvist J, Lopes LR, Lopes M, Luan J, MacArthur DG, Mangino M, Marenne G, März W, Maslen J, Matchan A, Mathieson I, McGuffin P, McIntosh AM, McKechanie AG, McQuillin A, Metrustry S, Migone N, Mitchison HM, Moayyeri A, Morris J, Morris R, Muddyman D, Muntoni F, Nordestgaard BG, Northstone K, O'Donovan MC, O'Rahilly S, Onoufriadis A, Oualkacha K, Owen MJ, Palotie A, Panoutsopoulou K, Parker V, Parr JR, Paternoster L, Paunio T, Payne F, Payne SJ, Perry JRB, Pietilainen O, Plagnol V, Pollitt RC, Povey S, Quail MA, Quaye L, Raymond L, Rehnström K, Ridout CK, Ring S, Ritchie GRS, Roberts N, Robinson RL, Savage DB, Scambler P, Schiffels S, Schmidts M, Schoenmakers N, Scott RH, Scott RA, Semple RK, Serra E, Sharp SI, Shaw A, Shihab HA, Shin S-Y, Skuse D, Small KS, Smee C, Smith GD, Southam L, Spasic-Boskovic O, Spector TD, Clair DS, Pourcain BS, Stalker J, Stevens E, Sun J, Surdulescu G, Suvisaari J, Syrris P, Tachmazidou I, Taylor R, Tian J, Tobin MD, Toniolo D, Traglia M, TybjaergHansen A, Valdes AM, Vandersteen AM, Varbo A, Vijayarangakannan P, Visscher PM, Wain LV, Walters JTR, Wang G, Wang J, Wang Y, Ward K, Wheeler E, Whincup P, Whyte T, Williams HJ, Williamson KA, Wilson C, Wilson SG, Wong K, Xu C, Yang J, Zaza G, Zeggini E, Zhang F, Zhang P, Zhang W; UK10K Consortium. Improved imputation of low-frequency and rare variants using the UK10K haplotype reference panel. Nat Commun 2015;6:8111.

24 McCarthy S, Das S, Kretzschmar W, Delaneau O, Wood AR, Teumer A, Kang HM, Fuchsberger C, Danecek P, Sharp K, Luo Y, Sidore C, Kwong A, Timpson N, Koskinen S, Vrieze S, Scott LI, Zhang H, Mahajan A, Veldink J, Peters U, Pato C, van Duijn CM, Gillies CE, Gandin I, Mezzavilla M, Gilly A, Cocca M, Traglia M, Angius A, Barrett JC, Boomsma D, Branham K, Breen G, Brummett CM, Busonero F, Campbell H, Chan A, Chen S, Chew E, Collins FS, Corbin LJ, Smith GD, Dedoussis G, Dorr M, Farmaki AE, Ferrucci L, Forer L, Fraser RM, Gabriel S, Levy S, Groop L, Harrison T, Hattersley A, Holmen OL, Hveem K, Kretzler M, Lee JC, McGue M, Meitinger T, Melzer D, Min JL, Mohlke KL, Vincent JB, Nauck M, Nickerson D, Palotie A, Pato M, Pirastu N, McInnis M, Richards JB, Sala C, Salomaa V, Schlessinger D, Schoenherr S, Slagboom PE, Small K, Spector T, Stambolian D, Tuke M, Tuomilehto J, Van den Berg LH, Van Rheenen W, Volker U, Wijmenga C, Toniolo D, Zeggini E, Gasparini P, Sampson MG, Wilson JF,
Frayling T, de Bakker PI, Swertz MA, McCarroll S, Kooperberg C, Dekker A, Altshuler D, Willer C, lacono W, Ripatti S, Soranzo N, Walter K, Swaroop A, Cucca F, Anderson CA, Myers RM, Boehnke M, McCarthy MI, Durbin R; Haplotype Reference Consortium. A reference panel of 64,976 haplotypes for genotype imputation. Nat Genet 2016;48:1279-83.

25 Yang J, Lee SH, Goddard ME, Visscher PM. GCTA: a tool for genome-wide complex trait analysis. Am J Hum Genet 2011;88:76-82.

26 Schweiger R, Fisher E, Rahmani E, Shenhav L, Rosset S, Halperin E. Using Stochastic Approximation Techniques to Efficiently Construct Confidence Intervals for Heritability: In. Research in Computational Molecular Biology. Cham: Springer, 2017:241-56.

27 Chang CC, Chow CC, Tellier LC, Vattikuti S, Purcell SM, Lee JJ. Second-generation PLINK: rising to the challenge of larger and richer datasets. Gigascience 2015;4:7.

28 Dey R, Schmidt EM, Abecasis GR, Lee S. A Fast and Accurate Algorithm to Test for Binary Phenotypes and Its Application to PheWAS. Am J Hum Genet 2017;101:37-49.

29 Chavent M, Kuentz-Simonet V, Labenne A, Saracco J. Multivariate analysis of mixed type data: The PCAmixdata R package, 2014

30 Sudlow C, Gallacher J, Allen N, Beral V, Burton P, Danesh J, Downey P, Elliott P, Green J, Landray M, Liu B, Matthews P, Ong G, Pell J, Silman A, Young A, Sprosen T, Peakman T, Collins R. UK biobank: an open access resource for identifying the causes of a wide range of complex diseases of middle and old age. PLoS Med 2015;12:e1001779.

31 Yang Q, Wang Y. Methods for Analyzing Multivariate Phenotypes in Genetic Association Studies. J Probab Stat 2012;2012:1-13.

32 Euesden J, Lewis CM, O'Reilly PF. PRSice: Polygenic Risk Score software. Bioinformatics 2015:31:1466-8

33 McEvoy B, Beleza S, Shriver MD. The genetic architecture of normal variation in human pigmentation: an evolutionary perspective and model. Hum Mol Genet 2006;15:R176-81.

34 Liu F, Visser M, Duffy DL, Hysi PG, Jacobs LC, Lao O, Zhong K, Walsh S, Chaitanya L, Wollstein A, Zhu G, Montgomery GW, Henders AK, Mangino M, Glass D, Bataille V, Sturm RA, Rivadeneira F, Hofman A, van IJcken WF, Uitterlinden AG, Palstra RJ, Spector TD, Martin NG, Nijsten TE, Kayser M. Genetics of skin color variation in Europeans: genome-wide association studies with functional follow-up. Hum Genet 2015;134:823-35.

35 Robles-Espinoza CD, Roberts ND, Chen S, Leacy FP, Alexandrov LB, Pornputtapong N, Halaban R, Krauthammer M, Cui R, Timothy Bishop D, Adams DJ. Germline MC1R status influences somatic mutation burden in melanoma. Nat Commun 2016;7:12064

36 Sturm RA. Skin colour and skin cancer - MC1R, the genetic link. Melanoma Res 2002;12:405-16.

37 McLaren W, Gil L, Hunt SE, Riat HS, Ritchie GR, Thormann A, Flicek P, Cunningham F. The Ensembl Variant Effect Predictor. Genome Biol 2016;17:122.

38 Wysocki K, Ritter L. Diseasome: an approach to understanding gene-disease interactions. Annu Rev Nurs Res 2011;29:55-72.

39 Yang J, Bakshi A, Zhu Z, Hemani G, Vinkhuyzen AA, Lee SH, Robinson MR, Perry JR, Nolte IM, van Vliet-Ostaptchouk JV, Snieder H, Esko T, Milani L, Mägi R, Metspalu A, Hamsten A, Magnusson PK, Pedersen NL, Ingelsson E, Soranzo N, Keller MC, Wray NR Goddard ME, Visscher PM; LifeLines Cohort Study. Genetic variance estimation with imputed variants finds negligible missing heritability for human height and body mass index. Nat Genet 2015;47:1114-20.

40 Krapohl E, Rimfeld K, Shakeshaft NG, Trzaskowski M, McMillan A, Pingault JB, Asbury K, Harlaar N, Kovas Y, Dale PS, Plomin R. The high heritability of educational achievement reflects many genetically influenced traits, not just intelligence. Proc Natl Acad Sci U S A 2014:111:15273-8.

41 Turley P, Walters RK, Maghzian O, Okbay A, Lee JJ, Fontana MA, Nguyen-Viet TA, Wedow R, Zacher M, Furlotte NA, Magnusson P, Oskarsson S, Johannesson M, Visscher PM, Laibson D, Cesarini D, Neale BM, Benjamin DJ; 23andMe Research Team, Social Science Genetic Association Consortium. Multi-trait analysis of genome-wide association summary statistics using MTAG. Nat Genet 2018;50:229-37.

42 Weedon MN, Lango H, Lindgren CM, Wallace C, Evans DM, Mangino M, Freathy RM, Perry JR, Stevens S, Hall AS, Samani NJ, Shields B, Prokopenko I, Farrall M, Dominiczak A, Johnson T, Bergmann S, Beckmann JS, Vollenweider P, Waterworth DM, Mooser V, Palmer CN, Morris AD, Ouwehand WH, Zhao JH, Li S, Loos RJ, Barroso I, Deloukas P, Sandhu MS, Wheeler E, Soranzo N, Inouye M, Wareham NJ, Caulfield M, Munroe PB, Hattersley AT, McCarthy MI, Frayling TM; Diabetes Genetics Initiative, Wellcome Trust Case Control Consortium, Cambridge GEM Consortium. Genomewide association analysis identifies 20 loci that influence adult height. Nat Genet 2008:40:575-83.

43 McClay JL, Adkins DE, Åberg K, Bukszár J, Khachane AN, Keefe RSE, Perkins DO, McEvoy JP, Stroup TS, Vann RE, Beardsley PM, Lieberman JA, Sullivan PF, van den Oord EJCG. Genome-wide pharmacogenomic study of neurocognition as an indicator of antipsychotic treatment response in schizophrenia. Neuropsychopharmacology 2011:36:616-26

44 Lee MK, Shaffer JR, Leslie EJ, Orlova E, Carlson JC, Feingold E, Marazita ML, Weinberg SM. Genome-wide association study of facial morphology reveals novel associations with FREM1 and PARK2. PLOS One 2017:12:e0176566.

45 Hill WD, Marioni RE, Maghzian O, Ritchie SJ, Hagenaars SP, McIntosh AM, Gale CR, Davies G, Deary IJ. A combined analysis of genetically correlated traits identifies 187 loci and a role for neurogenesis and myelination in intelligence. Mol Psychiatry; 15. 
46 Wang X, Sun J, Li C, Mao B. EphA7 modulates apical constriction of hindbrain neuroepithelium during neurulation in Xenopus. Biochem Biophys Res Commun 2016;479:759-65.

47 Prost G, Braun S, Hertwig F, Winkler M, Jagemann L, Nolbrant S, Leefa IV, Offen N, Miharada K, Lang S, Artner I, Nuber UA. The putative tumor suppressor gene EphA7 is a novel BMI-1 target. Oncotarget 2016;7:58203-17.

48 Choi H, Lee SH, Um SJ, Kim EJ. CACUL1 functions as a negative regulator of androgen receptor in prostate cancer cells. Cancer Lett 2016:376:360-6.

49 Voorhoeve PG, van Mechelen W, Uitterlinden AG, Delemarre-van de Waal HA, Lamberts SW. Androgen receptor gene CAG repeat polymorphism in longitudinal height and body composition in children and adolescents. Clin Endocrinol 2011;74:732-5.

50 Tsukasaki K, Miller CW, Greenspun E, Eshaghian S, Kawabata H, Fujimoto T, Tomonaga M, Sawyers C, Said JW, Koeffler HP. Mutations in the mitotic check point gene, MAD1L1, in human cancers. Oncogene 2001;20:3301-5.

51 Schizophrenia Psychiatric Genome-Wide Association Study (GWAS) Consortium. Genome-wide association study identifies five new schizophrenia loci. Nat Genet 2011:43:969-76.

52 Ng MC, Shriner D, Chen BH, Li J, Chen WM, Guo X, Liu J, Bielinski SJ, Yanek LR, Nalls MA, Comeau ME, Rasmussen-Torvik LJ, Jensen RA, Evans DS, Sun YV, An P, Patel SR, Lu Y, Long J, Armstrong LL, Wagenknecht L, Yang L, Snively BM, Palmer ND, Mudgal P, Langefeld CD, Keene KL, Freedman BI, Mychaleckyj JC, Nayak U, Raffel LJ, Goodarzi MO, Chen YD, Taylor HA, Correa A, Sims M, Couper D, Pankow JS, Boerwinkle E, Adeyemo A, Doumatey A, Chen G, Mathias RA, Vaidya D, Singleton AB, Zonderman $A B$, Igo RP, Sedor JR, Kabagambe EK, Siscovick DS, McKnight B, Rice K, Liu Y, Hsueh WC, Zhao W, Bielak LF, Kraja A, Province MA, Bottinger EP, Gottesman O, Cai Q, Zheng W, Blot WJ, Lowe WL, Pacheco JA, Crawford DC, Grundberg E, Rich SS, Hayes MG, Shu XO, Loos RJ, Borecki IB, Peyser PA, Cummings SR, Psaty BM, Fornage M, lyengar SK, Evans MK, Becker DM, Kao WH, Wilson JG, Rotter JI, Sale MM, Liu S, Rotimi CN, Bowden DW. FIND Consortium eMERGE Consortium DIAGRAM Consortium MuTHER Consortium MEta-analysis of type 2 Dlabetes in African Americans Consortium. Metaanalysis of genome-wide association studies in African Americans provides insights into the genetic architecture of type 2 diabetes. PLoS Genet 2014;10:e1004517.

53 Demerath EW, Guan W, Grove ML, Aslibekyan S, Mendelson M, Zhou YH, Hedman Å Sandling JK, Li LA, Irvin MR, Zhi D, Deloukas P, Liang L, Liu C, Bressler J, Spector TD,
North K, Li Y, Absher DM, Levy D, Arnett DK, Fornage M, Pankow JS, Boerwinkle E, ÅK $\mathrm{H}$, Li L-A IMR. Epigenome-wide association study (EWAS) of BMI, BMI change and waist circumference in African American adults identifies multiple replicated loci. Hum Mol Genet 2015;24:4464-79.

54 Rzehak P, Covic M, Saffery R, Reischl E, Wahl S, Grote V, Weber M, Xhonneux A, Langhendries JP, Ferre N, Closa-Monasterolo R, Escribano J, Verduci E, Riva E, Socha P, Gruszfeld D, Koletzko B. DNA-Methylation and Body Composition in Preschool Children: Epigenome-Wide-Analysis in the European Childhood Obesity Project (CHOP)-Study. Sci Rep 2017;7:14349.

55 Lotta LA, Gulati P, Day FR, Payne F, Ongen H, van de Bunt M, Gaulton KJ, Eicher JD, Sharp SJ, Luan J, De Lucia Rolfe E, Stewart ID, Wheeler E, Willems SM, Adams C, Yaghootkar H, Forouhi NG, Khaw KT, Johnson AD, Semple RK, Frayling T, Perry JR, Dermitzakis E, McCarthy MI, Barroso I, Wareham NJ, Savage DB, Langenberg C, O'Rahilly S, Scott RA; EPIC-InterAct Consortium Cambridge FPLD1 Consortium. Integrative genomic analysis implicates limited peripheral adipose storage capacity in the pathogenesis of human insulin resistance. Nat Genet 2017;49:17-26.

56 Castaño-Betancourt MC, Evans DS, Ramos YF, Boer CG, Metrustry S, Liu Y, den Hollander W, van Rooij J, Kraus VB, Yau MS, Mitchell BD, Muir K, Hofman A, Doherty M, Doherty S, Zhang W, Kraaij R, Rivadeneira F, Barrett-Connor E, Maciewicz RA, Arden N, Nelissen RG, Kloppenburg M, Jordan JM, Nevitt MC, Slagboom EP, Hart DJ, Lafeber F, Styrkarsdottir U, Zeggini E, Evangelou E, Spector TD, Uitterlinden AG, Lane NE, Meulenbelt I, Valdes AM, van Meurs JB. Novel Genetic Variants for Cartilage Thickness and Hip Osteoarthritis. PLoS Genet 2016;12:e1006260.

57 Mullin BH, Walsh JP, Zheng HF, Brown SJ, Surdulescu GL, Curtis C, Breen G, Dudbridge F, Richards JB, Spector TD, Wilson SG. Genome-wide association study using familybased cohorts identifies the WLS and CCDC170/ESR1 loci as associated with bone mineral density. BMC Genomics 2016;17:136.

58 Dyment DA, Smith AC, Alcantara D, Schwartzentruber JA, Basel-Vanagaite L, Curry CJ, Temple IK, Reardon W, Mansour S, Haq MR, Gilbert R, Lehmann OJ, Vanstone MR, Beaulieu CL, Majewski J, Bulman DE, O'Driscoll M, Boycott KM, Innes AM; FORGE Canada Consortium. Mutations in PIK3R1 cause SHORT syndrome. Am J Hum Genet 2013;93:158-66.

59 Majumdar A, Haldar T, Bhattacharya S, Witte JS. An efficient Bayesian metaanalysis approach for studying cross-phenotype genetic associations. PLoS Genet 2018;14:e1007139. 